\title{
Fyra berättelser om arbete: Om arbets- attityder och mening och varför man ska arbeta (Del 1)
}

\section{Av Roland Hallgren}

\section{Inledning}

Michel de Montaigne säger i en av sina essayer att: "Det viktigaste vi kan lära ungdomen är vakenhet och aktivitet". ${ }^{1}$ Min egen fria tolkning av denna femtonhundratalsutsaga är att författaren menar att den äldre generationen ska lära de yngre samhällsmedborgarna att vara nyfikna, kritiska, kreativa, skapande och arbetsvilliga. Att förverkliga detta ideal fullt ut under femtonhundratalet var eventuellt lika svårt som idag. Kanske är det ändå så att arbetet som livsprojekt inte är lika viktigt för ungdomar idag som förr och inte längre anses ge en särskild mening åt livet. Det måste i vilket fall som helst vara "rätt" arbete för att få en djupare mening. Detta arbete behöver inte vara ett lönearbete i traditionell mening utan kan i stället vara ett "fritidsarbete" som mer är ett individuellt projekt än ett arbete i samhällsnyttans tjänst. ${ }^{2}$ Den nya tekniken gör också människor mer tillgängliga och arbetsplatsen liksom arbetstiden blir alltmer flexibel. Förändringar sker, men frågan om arbetets betydelse $\mathrm{i}$ det mänskliga livet är fortfarande angelägen.

Ungdomars livsstil har ändrat sig och vi har numera, om vi jämför med när jag växte upp i en småstad under femtio- och sextiotalet, ett förändrat och heterogent Sverige med allt mindre hushåll, fler splittrade familjer, segregerat mellan stad och land och mellan olika förorter i storstadsmiljö samt mellan olika samhällsgrupper. Samhället har uppenbara problem med att integrera nya folkgrupper i "folkhemmet". Ökar otrivseln har det sannolikt också betydelse för brott och spridning av droganvändning. Människor flyr från verkligheten. Tröstätning och alkohol samt materiell överkonsumtion dövar tillfälligt ångesten och ledan men bidrar ytterligare till passivitet och till att människor fastnar i skuldfällan. Arbetskraften är geografiskt orörlig och enligt larmrapporter blir svensken allt fetare. Ändå uppmanas vi ofta till en ständigt ökad konsumtion. Du är alltid fri att konsumera. Reklamens glada budskap är ofta konsumera mera - det hjälper. Men är ett köpkraftens evangelium verkligen något att bli frälst på? Finns samhällsekonomisk täckning för vår livsstil eller lever vi på lån, upptagna av nuet och föga intresserade av framtiden utom när det spekuleras om jordens undergång? Finns det rentav en framtidsrädsla?

Är detta en vrångbild av Sverige? Kanske delvis. En sak som däremot verkar säker är att där livsstilar ändras där ändras på sikt också grundläggande värderingar och attityder.

1 Michel de Montaigne 1962:248.

2 Föreläsning på Framtidsdag 2/3 2005. Bernhard Lüthi från Kairos Future AB. 
Under det kinesiska första maj-firandet i Beijing delas fortfarande hedersutmärkelsen "Arbetets hjältar" ut. Socialistiska arbetshjältar korades även i det forna Sovjetunionen och liknande utmärkelser fanns i andra östländer. Kanske var Sveriges anonyma hjältar 40-talisternas föräldrar. Jan Forslin, professor i arbetsvetenskap på KTH i Stockholm tycks mena så när han säger; "Jag kallar dem för arbetets hjältar. De byggde det moderna Sverige, jobbade sex dagar i veckan, gick på kvällskurser och läste till tekniker på helgerna. Allt för att deras barn skulle få ett bättre liv". ${ }^{3}$ Denna tid av hårt arbete där ord som stress och utbrändhet var okända begrepp är visserligen inget vi längtar tillbaka till. Men vilka är dagens hjältar? Vad är vi villiga att offra för framtiden? Vilka är våra drivkrafter?

\section{Vad är arbete?}

Det finns olika definitioner och aspekter på vad arbete är. Arbetet kan definieras utifrån bland annat ekonomisk, teologisk (från kristen eller annan religion) och filosofisk etisk synvinkel. Det spänner mellan egots krav på självförverkligande och förverkligandet av ett högre mål eller att förverkliga idén om (Guds eller Marx) plan med mänskligheten och världen. Arbete är ett mångtydigt begrepp som inte bara har med försörjningen att göra. Lennart Koskinen citerar C.-H. Grenholm där han menar att det är "en varaktig ändamålsinriktad, intellektuell och/eller manuell mänsklig verksamhet som har ett annat syfte än det nöje själva sysselsättningen ger." ${ }^{4}$ Arbete är en aktivitet som mestadels producerar något (tjänster eller ger värde) för andra. Arbete kan också utföras maskinellt eller genom automatisk produktion. Arbete ses kanske enklast som en del av världens naturliga flöde och människan måste av nödvändighet delta i detta. ${ }^{5}$ Att definiera arbete är nog vid första tanken, för de flesta av oss, inget problem, men ställs man inför en konkret fråga att göra så finner man troligen att uppgiften inte är så lätt. Definitioner är också kulturbundna. Det som kan betraktas som fri lek i somliga kulturer kan av andra uppfattas som mödosamt och påtvingat arbete.

Författaren Miroslaw Volf definierar arbete som en form av instrumentell aktivitet: "Work is honest, purposeful, and methodologically specified social activity whose primary goal is the creation of products or states of affairs that can satisfy the needs of working individuals or their co-creatures, or (if primarily an end in itself) activity that is necessary in order for acting individuals to satisfy their needs apart from the need for the activity itself. " ${ }^{\circ}$ Det kan också tilläggas att det inom engelsk språkuppfattning ibland görs en distinktion mellan labor och work/play. ${ }^{7}$ Åtskilligt kan sägas om definitionen av arbete och de varianter av sådana definitioner som finns, men denna orientering räcker tills vidare.

3 DN. Ekonomi. Nätupplagan onsdag 1 mars 2006.

4 Lennart Koskinen 1994:91 och 87-106. Jfr E. Bischofberger/H. Fagerberg 1980:121-133.

5 The New Encyclopaedia Britannica. Vol 29 (15th ed Knowledge in Depth):916.

6 Miroslaw Volf 1991: 10f.

7 Donald Clark Hodges 1962:359-372. 


\section{Arrityder till arbete och yrke}

Synen på arbete är en viktig framtidsfråga. Men vad tycker egentligen de som är unga idag om arbetets mening och värde? Troligtvis är det fortfarande så att många anser att basala behov som försörjning och trygghet måste tillgodoses men det är inte alls säkert att detta ska ske genom arbete. Det finns kanske en uppfattning om att staten ska garantera försörjning och trygghet oavsett om medborgaren vill arbeta eller ej?

Finns det då något som kan kallas arbetsglädje? Ett begrepp som arbetsglädje har kanske aldrig varit någon bra term för att beskriva arbetets värde. Arbeta var något som man måste göra och snarare mer av nödvändigt tvång än att det skapade någon personlig eufori även om den kreativa arbetsglädjen inte får underskattas. Professor Forslin som jag nämnt tidigare, menar att när medelklassen växte fram blev det prestige snarare mer än arbetsglädje som blev yrkeslivets drivkraft. Denna form av prestige hänger sannolikt samman med det vi kallar yrkesstolthet. Känslan av exklusiv kunnighet och oumbärlighet har troligtvis alltid skapat yrkesstolthet mer eller mindre accentuerat och relaterat till olika yrkesgrupper. Kanske traditionellt mest förankrat till hantverksskicklighet, medicinsk kirurgisk precision och händernas finmotoriska arbete men numera också relaterat till den skicklige dataoperatörens insatser. Ett traditionellt uppskattat hantverk är snickarens. Kanske bland annat därför att kopplingen till kristendomens timmermansideal fortfarande är stark. Historikern K. G. Jan Gustafson berättar med inlevelse om hur han vid ett tillfälle upplevde den pensionerade snickaren Karl Johansson i arbete. I symbios med sina verktyg och råämnen blev han ett med uppgiften. Yrkesstolthet och kunnighet får här närmast mystika och mytiska dimensioner. ${ }^{8}$

Det är kanske så att det finns ett djupt rotat behov av att få göra en arbetsinsats som uppskattas av andra. En stor del av en människas självrespekt kommer ur känslan att få vara nyttig. Att vara nöjd med sin arbetsinsats och få bli bejakad av andra är en viktig del i en människas liv. Tar människan skada av att berövas detta? Är arbete livsnödvändigt?9 Det är nog fortfarande så att man i hög grad förverkligar sig själv genom sitt arbete. Du är, i hög grad, vad du arbetar med. På frågorna; Vad gör du? Vad är du? Vad sysslar du med? - svarar man nog ofta med att uppge sitt arbete eller den pågående utbildning som ska leda fram till ett arbete. Du definierar och har din identitet genom ditt yrke, arbete eller titel. Denna attityd som för inte så länge sedan till och med följde dig in i döden och på gott och ont ristades in på gravstenen. Ett faktum som gör en historisk kyrkogårdsvandring så intressant. Vår nutida värdenivellering när det kommer till arbete och titlar är även den på gott och ont. Nu sägs det att ingenstans i världen identifierar sig människor så lite med sitt arbete som i Sverige. Detta enligt en blogg med akademiska synpunkter på World Values Survey från 2009. Någon direkt undersökning inom worldvaluessurvey om arbetsmoral/arbetsetik eller attityder till arbete i Sverige i jämförelse

8 K.G. Jan Gustafson 1998:161.

9 Carl-Henrik Grenholm 1977:14. Jfr Shirley Dex 1988 och Lasse Siurala 1982. 
med andra länder har inte utförts. Däremot sägs 2011 att svenska ungdomars positiva attityd till demokrati försämrats. ${ }^{10}$

En stor skillnad från tidigare är att vad som var att betrakta som ett arbete förr definieras annorlunda nu. Att vara en "backpacker" är ett arbete i det personliga upptäcktsreseprojektet. Att vara fotbollsspelare, utförsåkare, golf- och tennisspelare eller skateboardåkare är arbeten som för inte så länge sedan var ren fritidssysselsättning/fritidsaktivitet oavsett vilken nivå man befann sig på. Att spela nätpoker är en annan sysselsättning som blivit ett arbete eller i alla fall kan ge spelaren en relativt osäker försörjningsmöjlighet. Arbetaren av idag, enligt kritikern Erik Wallrup övervakar mer än tillverkar. (SvD s14 24/5 2011) Han eller hon kan ju också hamna på ett call-center och överraska någon med ett oönskat samtal en söndagskväll. Att studera (skolarbete) är också ett arbete på skilda nivåer från att gå i förskola till att läsa vid ett universitet men det är inte många år sedan det betraktades som ett medel för att skaffa sig ett "ordentligt" arbete. När ska du börja arbete? - var en fråga jag ofta fick under min studietid som vuxen, men så kom jag också från en familjetradition utan större erfarenhet av högre studier. Ett intressant sätt för samhället att värdera en medborgares studier som en form av "hederligt" arbete vore om det fanns möjlighet att få studielön. Efter avslutade studier är det också avgörande för det personliga välbefinnandet att man inte utbildat sig till arbetslöshet vilket ibland syns vara fallet i nuläget.

En del kulturer har en mer positiv attityd till studier som en form av arbete än andra, exempelvis den judiska. Där har tankens kritiska arbete genom den rabbinska traditionen och också av social och politisk-ekonomisk nödvändighet för ett utsatt folk alltid stått högt i kurs. Under pressade situationer är det enligt min mening ofta så att arbetet får större betydelse än under ett normalförhållande. Arbetet för en människa får då en ren hälsoaspekt och blir till psykisk och fysisk friskvård. Man överlever genom sitt arbete. Upplevs arbetets "flow" så glömmer man sig själv. Efteråt känner, i alla fall jag ofta, ett välmående. Arbetet blir till en "katharsis", du renas. Den tjeckiske författaren Bohumil Hrabal liknar människan vid en oliv - det är först under press man kan ge ifrån sig sitt bästa. Denna positiva press måste så klart skiljas från negativ stress som oftast låser en persons kreativitet.

Så några ord om ålderdom och arbete. Äldre friska personer vill som regel arbeta så länge som möjligt - att åldras i sin gärning - som en bibelvers i Syraks bok säger. I vårt samhälle där medellivslängden ökar och ekonomiska förutsättningar och pensionsförmåner ändras får man förutsätta att människor i framtiden kommer att arbeta allt längre upp i åldrarna. Då blir det viktigt att attityder inte spelas ut mot varandra så att yngre potentiella arbetstagare ställs mot äldre anställda, utan att arbetsgivare drar nytta av både erfaren och yngre mer oerfaren kompetens. Så var det ju mestadels i det gamla svenska bondesamhället och fortfarande på många håll i världen där generationerna går omlott.

En annan viktig attityd till arbete kan formuleras som; När ska man inte arbeta? Det sägs ibland av samhällsdebattörer och andra att "trötthet" hos en del ungdomar är ett

10 Synpunkter.blogspot.com/2008/09world-values-survey.html (2/4 2009), www.worldvaluessurvey.org. 
fullgott skäl för sjukskrivning. Under min egen uppväxt på femtio- och sextiotalet kallades ofta detta för "lathet" och ansågs inte legitimt för att stanna hemma varken från skola eller arbete. (Se avsnittet Arbetsmoral nedan) Människor är kanske i grunden lika trötta eller bekväma då som nu men uppfattningen visar på ords betydelseförändring över tid och på vad som anses som ett godtagbart skäl. Attityder förändras. Det sker uppenbarligen även moralförändringar. Det som var ett omöjligt synsätt förr är möjligt och accepterat idag. I serien Medelålders Plus säger sonen till sin far "Farsan, min generation är inte så fokuserad på att jobba hela tiden som din var. Å ni mådde ju inte bra av allt det där jobbandet. Inte sant?" (Barometern 6/5 2011) Livet utgörs numera inte bara av arbete och helgvila utan man ska också njuta och leva livet.

\section{Arbetsmoral}

Utgör arbetet och den personliga arbetsinsatsen en värdegrund i dagens samhälle? Jag tror inte att arbetet betraktas som speciellt viktigt längre eller att det $i$ allmänhet motiveras utifrån en etisk grund. Arbetsetik och arbetsmoral är nog moment som inte så ofta kommer till tals vare sig i skol- och utbildningsmiljö eller i andra informations- och diskussionssammanhang som exempelvis det dagspolitiska. Detta gäller nog också arbetets mening, som kanske om det diskuteras uttrycks mest i termer av ekonomisk vinning. Tas arbetet upp i nämnda sammanhang är det nog också i dess betydelse för identitetsskapande. Vän av ordning kanske undrar vad författaren menar med etik och moral. Enkelt uttryckt menar jag med etik de system av regler och normer som ligger till grund för de praktiska handlingarna, det vill säga moralen som är effekten av etiken.

Det är en rättighet att vara arbetslös (friställd/arbetssökande) men det finns inte någon skyldighet att arbeta. I Sverige är det ungefär, beroende på hur man räknar, en miljon utanför arbetslivet som är i yrkesaktiv ålder. Det är siffror som skrämmer. Finns det något allvarligare för ett lands framtid än en mängd sysslolösa unga människor? Det sägs ibland att det växt fram en bidragskultur i Sverige där det går att spåra en attityd, kanske främst bland yngre, som vet att om de inte får något arbete så finns det alltid en möjlighet att leva på bidrag. Sådana attityder utvecklas över tid till sanningar som är farliga för ett lands framtid. Arbetet borde i första hand ses som både en mänsklig rättighet och en skyldighet. Betraktas arbetslöshet som ett accepterat normalläge så är samhället i kris.

Är det så att solidaritet och arbetsansvar har minskat? Professor Göran Brulin menar att höga sjukskrivningstal beror på människors låga arbetsmoral." Eventuellt är det så att arbetsetiken luckrats upp och att det personliga ansvaret för att arbeta inte är så uttalat längre? ${ }^{12}$ Kanske ligger det något i detta, men det vi kallar stressrelaterade sjukdomar är säkert också en viktig variabel i samband med ökad sjukfrånvaro. Är det så att alltfler vantrivs i den kultur vi själva skapat? Vi är som så ofta offer för oss själva.

Att förstå sina personliga förutsättningar och se nyktert på sin aktuella situation är

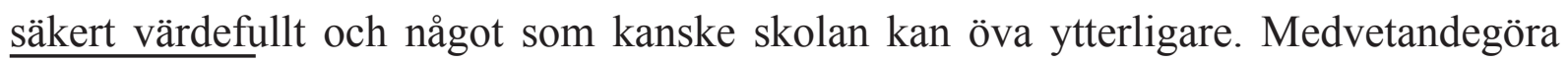

11 www.tco.se/ArticlePages 23/11 2005.

12 Barbara Goodwin 2000. 
först och åtgärda sedan. En viktig diskussion som bör tas upp när det gäller att bygga upp en fungerande arbetsmoral är att betrakta sin egen arbetsinsats som en del i något som är större än det individuella projektet. Får man i sitt arbete en känsla av verkligt sammanhang blir sannolikt viljan till arbete stärkt. Den positiva upplevelsen av arbete liksom hälsan i allmänhet förbättras nog om man jämför med personer som saknar denna känsla av sammanhang. ${ }^{13}$

Peter Skogman Thoursie menar enligt en artikel i DN att unga män under 36 år har sämre arbetsmoral än andra. Detta gäller män i högre grad än kvinnor. ${ }^{14}$ De drar sig inte för att smita från arbetsplatsen för att fira sin födelsedag för att handla hem, celebrera och nyktra till på arbetsgivarens bekostnad. Sannolikt grundläggs värderingar om arbetsmoral tidigt. En undersökning av 550 gymnasieelever visar att flickorna nästan dubbelt så ofta som pojkarna var positiva till arbete. ${ }^{15}$ Har då kvinnor bättre arbetsmoral? Min intuition och erfarenhet av undervisning säger att det är så. I den så kallade PISA-undersökningen kan man se att svenska skolledare skattar både lärares och elevers arbetsmoral högt trots att svenska elever i OECD är de som oftast kommer för sent till lektionerna. ${ }^{16}$ Har vi då för låga krav? Vi kanske lever i en tid där allt ska fixas snabbt och där vi är mer bortskämda och självupptagna än vad vi varit under tidigare århundraden. Samtidigt vet vi att stressen i arbetslivet är uttalad. Visserligen har väl stressen alltid följt människan som en konstant varningssignal. Problemet är kanske som Lennart Levi säger att vi biologiskt sett är en stenåldersmänniska vid datorn. ${ }^{17}$ Tekniken verkar ha försprång framför vår biologiska anpassningsförmåga och det gör oss mer stressade i ovana situationer.

Det är klart att man också måste fråga sig vad som menas med den gamla tidens arbetsmoral. Det ligger nära till hands att tänka på Martin Luther och vad han lär ha sagt; "Vill du övervinna djävulen, måste du arbeta, han giver icke vika för dem som äro sysslolösa och undvika besvär." ${ }_{18}$ Att arbeta hårt hindrar med andra ord tillfällen till synd. Det finns i detta en syn på den ideala människan som en ständigt verksam maskin. Är du sysselsatt är du nyttig men fritiden i form av vila är farlig för då är frestaren som mest verksam. Djävulen verkar älska den late och hata den arbetsamme. Det kategoriska anslaget i Luthers utsaga innebär även att det finns ett förhållande mellan arbete och tvång. Du skall arbeta vare sig du vill det eller inte. Arbetet blir då näst intill ett slavarbete. Samtidigt är det uppenbart att det finns ett förhållande mellan arbete och social rättvisa där min existens är beroende av andras arbete. ${ }^{19}$

Det finns en uppfattning hos unga att somliga svenskar har en högre arbetsmoral än andra. Vid en undersökning av elever i Åk 9 ( Nu 03) om bland annat elevattityder till solidaritet fann forskarna att "Cirka tre fjärdedelar av eleverna tycker att det är bra att

13 Jfr Lennart Levi 2002:29.

14 DN. Ekonomi. 15/11 2005. Även FIEF Working paper No 203 (www.fief.se) 23/11 2005.

15 (www.lu.se) Se pressmeddelande Medicin, vård och hälsa 23/11 2005.

16 www.skolverket.se. Resultat PISA 2003 då matematik var huvudområdet 23/11 2005.

17 Lennart Levi 2002:15, 19.

18 Nathan Söderblom 1919:159.

19 Lillemor Erlander 1975: 148-170 och C-H Grenholm (red.) 1977:13-25. 
svenskar får tillfälle att hjälpa människor i nöd och att invandrare för in ny kultur, men ca $40 \%$ håller med om påståendena att invandrare inte vill arbeta och att de har farliga religioner" ${ }^{20}$ Vilken betydelse kan den typen av attityder få för det framtida Sveriges sammanhållning och vad gör skolan och det övriga samhället åt detta?

\section{Arbetets mening och värde}

Är ett intellektuellt tankearbete mer värdefullt än det som i alla fall förr i tiden benämndes - "ett hederligt kroppsarbete"? Eller är det ett finmotoriskt kreativt hantverk som är det förnämsta arbetet? Sådana frågor är nog rätt fruktlösa. Däremot kan man resa frågan om vad som är ett meningsfullt arbete och finns ett sådant bör det rimligtvis också finnas ett meningslöst arbete. Om vi börjar med det meningslösa arbetet så är det närmast att betrakta som ett straff. I den grekiska mytologin kan vi erinra oss Sisyfos uppgift att rulla upp ett klippblock för att sedan se det rulla ner igen. Detta skapar knappast arbetsglädje. Det är klart att arbetets mening är kopplat till nytta och till de arbetskamrater man har, till glädjen av att vara behövd och betyda något och vara insatt i en arbetsgemenskap. Man utvecklas och stimuleras genom sitt arbete och man känner som man sa förr "att man gör rätt för sig och inte ligger någon till last". Upplever du i ditt arbete att du har inflytande över din egen arbetssituation så mår du också sannolikt bättre. Cancerforskaren Georg Klein anser att vi mår som allra bäst av att arbeta och därför mår dåligt när vi inte har något att göra. Han menar att dagens arbetsliv inte ger människor den känsla av utmaning och inre belöning som behövs för att må bra. Samtidigt som Sverige är en av världens rikaste nationer så är vi också en bland de sjukaste. ${ }^{21}$ Detta i meningen sjukskrivningstal och hög arbetsfrånvaro. Här finns verkligen anledning att reflektera över vad rikedom och välstånd egentligen är, men också över vad priset är för att uppnå detta.

Arbetet måste värderas utifrån sitt sammanhang. Det finns ofta ett finstämt förhållande mellan arbete och hälsa och inte sällan är ett trivsamt arbete friskvård. Arbetet handlar också om rätten till en tillfredställande ersättning och en människovärdig tillvaro. Deklarationen om de mänskliga rättigheterna talar om att "Envar har rätt till arbete, till fritt val av sysselsättning, till rättvisa och tillfredställande arbetsförhållanden och till skydd mot arbetslöshet." ${ }^{22}$ En vision som inte låter sig uppnås så lätt. Det verkar som om människans förhållande till arbete under lång tid har präglats av en ambivalent inställning. " $\AA$ ena sidan är arbete ett nödvändigt ont, ett villkor för överlevnad. Å andra sidan en del av själva livet, en viktig social arena, kanske den viktigaste. Arbetet är även en betydelsefull plattform för individuell utveckling och skapande." ${ }^{23}$ Det aktiva livet "vita activa" består av en lång kedja av arbetsverksamhet och handlingar av annan natur. Det är nödvändigt att det är så för hur skulle ett samhälle utan arbete se ut. Arbetet i sig är det primära, viktigare än produkten, för livet självt är arbetets grundvillkor. Man kan ibland

20 Rune Jönsson/Bodil Liljefors 2005:20.

21 Liselotte Englund 2005: 6f.

22 Artikel 23.

23 I. Jegers/M. Lindgren 1992:84. 
fråga sig om det förakt för (kropps-) arbete som fanns under antiken har förts över till det kapitalistiska och post-moderna västerlandet. ${ }^{24}$

Under antiken var det de ofria slavarna som utförde kroppsarbete och skötte reproduktionen av nya individer till det proletariatet som gjorde tjänst åt de arbetsbefriade. Deras arbete var bokstavligt och bildligt bundet. Det var de fria männen som utförde fritt arbete och kunde leva för sitt arbete medan slavproletariatet måste arbeta (tjäna) för att leva. ${ }^{25}$ Länsplikten i det feodala och medeltida Europa innebar bland annat att trohet mot länsherren bekräftades genom löfte att ställa upp med arbetskraft och vapen. Andra ska arbeta och andra ska skydda mig mot att jag betalar mig fri från detta. Västerlandets stater har också ofta i imperialistisk och kolonialistisk anda dikterat för underkuvade länder om vilken medicin som gäller, alltså "värdet av hårt och regelbundet arbete." ${ }_{26}$ Töres Theorell som är professor i psykosocial medicin menar att; "I det gamla jägarsamhället betedde man sig kanske som lejon, det vill säga långa perioder av slö passivitet kan ha växlat med perioder av extremt stor aktivitet." ${ }^{27}$ Kanske är det så att människan är lat av naturen och att all produktion utöver det nödvändigaste måste tvingas fram med" morötter och piska" eller genom "bröd och skådespel".

På nyhetssändningar i radio och TV den 13 september 2012 och i tidningar dagen efter kritiserar tenniscoachen Mats Wilander i belgisk press svenska ungdomars träningsvanor. Han menar att något tennisunder lär inte längre ske för att ungdomar nuförtiden är både för lata och för feta. För få ungdomar är enligt honom beredda att offra sin bekvämlighet för framgångar på tennisbanan. Det kan vara angeläget att reflektera över betydelsen av att lata sig och om det nu är så att människan är det enda egentligt medvetet arbetande djuret. Lin Yutang säger "Hur outrannsaklig är inte vår civilisation vars människor sliter och arbetar och grubblar sig till gråa hår för att tjäna sitt bröd, men som alldeles glömt bort att leka!"”28 Att kombinera nyttighet med lagom delar av att lata sig och leka är en svår livsekvation men kanske en nödvändighet för att finna vägen till det goda arbetets glädje. Om nu människan är både lat och arbetsam så är det balans som måste eftersträvas. Fritiden bör kanske vara mer oorganiserad och mer fylld av frihet och "nyttig" lek än den som regel är. Sigmund Freud lär en gång ha svarat på frågan om vad som är stommen i ett gott liv - 'lieben und arbeiten', älska och arbeta. Om författaren Sven Delblanc läst Freud vet jag inte men i romanen Maria Ensam skriver han:

"Arbete och kärlek heter de två värden som livet har att skänka oss, arbete och kärlek heter de lemmar varmed vi rör oss genom tiden och omdanar världen och vidrör och smeker vår nästa. Arbete och kärlek heter de värden som räknas, allt annat är fåfänglighet." (s17f)

24 Hannah Arendt 1998:31ff, 123f.

25 Notera att en del språk har olika ord för bundet respektive fritt arbete. Med labour (eng) menas mer det ofria arbetet medan work mer signalerar det fria arbetet.

26 Marvin Harris 1975:466.

27 Töres Theorell 2005: 8.

28 Lin Yutang 1999:134. Se även 122ff VII. 
Lennart Levi, stressforskningspionjär i Sverige utvecklar detta och menar att det är arbete, kärlek och lek. ${ }^{29}$ Arbetsglädje är så vitt jag kan finna det närmast av andlig art. Brinner man för ett arbete eller en arbetsuppgift så växer glädjen oftast fram naturligt. Ursprungligen religiösa termer som entusiasm och inspiration faller i tankarna om man vill förklara vad arbetsglädje består av. Arbetssituationen för många människor är som vi vet inte alls tillfredställande. Att känna sig exploaterad och maktlös och uppleva främlingskap inför arbetets mening och värde drabbar nog de flesta av oss någon gång under ett arbetsliv. Adam Smith skulle kalla det för alienation och Marx skulle fylla i med att det trots allt är en evig nödvändighet att arbeta och att historien är en produkt av arbete. Marx hade en i stort sett positiv syn på arbete även om arbetet dock ska upphöra när kommunismen en gång förverkligats. Är det som Hannah Arendt menar ett val mellan "produktiv träldom och improduktiv frihet"? ${ }^{30}$ Arbete är nödvändigt för försörjningen men är det verkligen självförverkligande? Är det ett nödvändigt ont som kan ge ett gott resultat eller är det gott i sig eller bara ont?

Det goda arbetet som jag ser det är ett kreativt, humant och stimulerande arbete där den arbetande känner sig både uppskattad och behövd. Att bli sedd i sitt arbete och bekräftad som duglig är nödvändigt för en stabil arbetsglädje. Det goda arbetet är också god friskvård. Arbetet skapar tillsammans med fritiden en meningsfylld helhet. Båda delarna är livsnödvändiga men bör skiljas åt. Detta är en sanning som mången arbetsgivare skulle ta till sig och verka efter. Sannolikt upplevs inte alla arbeten så positivt som idealen föreskriver men strävan måste vara att skapa värde och mening i alla yrken och arbetsuppgifter. Det kan också påpekas att det rent principiellt finns en poäng $\mathrm{i}$ att det idoga arbetet är fyllt av disciplin, målinriktning och engagemang. Efter ett väl utfört arbete är det inte ovanligt att den arbetande känner sig nöjd och väl tillfreds med den vila och avkoppling som följer. Detta har med välbefinnande att göra och jag tror att många känner igen sig. Upplevelsen av en väl utförd uppgift är så god som någon $\mathrm{i}$ en tid där mer ofta vill ha ännu mer och där det mesta mäts i ekonomisk vinning. Kanske är förnöjsamhet också ett bortglömt värde idag? Arbetets värde måste också betraktas från både ett kollektivt och från ett mer personligt/egoistiskt perspektiv. Det finns inga betydelselösa arbetsinsatser om de utförs med goda intentioner och efter bästa förmåga. Det goda arbetet har mer än ett instrumentellt värde. Det kan vara gott att arbeta för själva arbetets skull. Det kan också vara gott att utföra något nyttigt som kommer andra tillgodo. Det verkar onekligen så som att människan är en kreativ varelse och är hon det så är hon ju skapad för att arbeta och kan knappast leva fullt ut och må bra utan någon form utav arbete. Att arbeta är kanske även att uppnå mänsklig värdighet. Arbetet är som bäst när det upplevs som betydelsefullt och helst också är njutningsfullt. ${ }^{31}$

Arbetets mening kan lättare synliggöras om man delar upp det i olika aspekter. Det finns en värdeaspekt där arbetet bedöms som viktigt både för en själv och för andra. Det finns en kompetensaspekt som berör ens egen medvetenhet om den egna dugligheten.

29 Lennart Levi 2002:289f.

30 Hannah Arendt 1998:148.

31 Jfr Miroslaw Volf 1991:196ff. 
Det finns för det tredje en belöningsaspekt som rör sig om ekonomisk ersättning och bekräftelse samt för det fjärde en existentiell aspekt som handlar om arbetsglädje och personlig tillfredställelse. ${ }^{32}$ För att allt detta ska upplevas behövs mänskliga och goda arbetsmiljöer som är skyddade av en väl fungerande arbetslagstiftning. Att minska den ofrivilliga arbetslösheten och ge människor möjlighet att uppleva det goda arbetets glädje är en utmaning för det demokratiska samhället.

Den kanadensiske filosofen Charles Taylor menar att den moderna människan saknar känslan av ett högre ändamål och något som är värt att dö för. Detta kan enligt filosofen Per Bauhn göra att döden blir mer skrämmande "och överlevnad i sig snarare än något att leva för blir vägledande." ${ }_{33}$ Livet blir självbespeglande och tomt på högre värden. Vi behöver med andra ord meningsgivande projekt som har betydelse för fler än oss själva. Arbetet kan i bästa fall utgöra ett sådant meningsprojekt.

\section{En berättelse om arbete och religion}

Arbetets betydelse för kulturen ska inte underskattas. Utan arbete ingen kultur. ${ }^{34}$ I denna berättelse ska jag översiktligt ta upp några kulturers syn på arbete som det behandlas $\mathrm{i}$ skriftlig och till största delen religiös tradition. Jag kommer att ta exempel från både nu levande- och forntida klassiska kulturtraditioner. Med andra ord tas exempel från texttraditioner som fortfarande har normerande aktualitet i de kulturer där de har sitt ursprung och från texter som härstammar från nu icke levande kulturer samt från annan litteratur om dessa båda traditioner. I den första gruppen ingår studier av Bibel- och Korantexter men även inblick i indisk tradition. I den andra gruppen ges bland annat exempel från mesopotamisk forntida tradition. Med litteratur menas i detta sammanhang berättande texter om folks seder och bruk. Även samlingar av talesätt och ordspråk kommer till viss användning. Avsikten är att ge läsaren en översiktlig berättelse om människors attityder till arbete med exempel tagna från olika tid och rum.

\section{Forntida kulturer}

Vår kunskap om förhistoriska miljöers syn på arbete är helt bunden till att försöka få artefakter som föremål, bilder och symboler att berätta, då några skriftliga dokument inte föreligger. Utgrävda miljöer som olika husgrunder eller miljöer som gravar kan också tyst berätta en del om synen på arbete. En form av ett utsökt och uppskattat hantverk i de forntida kulturerna var kanske de föremål som offrades som gåvor till de döda? Rituellt agerande och gravskick i den mån det kan beläggas vittnar om ett arbete i tjänsten för gudar och förfäder. Högar, dösar, hällkistor och resta stenar krävde samordnade och massiva arbetsinsatser så gjorde även byggande av långhus och andra permanenta och tillfälliga bostäder. Men vilket värde man tillskrev själva arbetsinsatsen vet vi inte. Var det frivilligt arbete eller ett slavarbete? Allt detta är svårtolkat. Genom olika naturveten-

32 Jfr Lars Ryberg 2002:101.

33 Per Bauhn1988:3.

34 Arne Helldén 1979. 
skapliga metoder kan man undersöka boplatser och gravfynd för att se vad människor jagade, samlade, odlade och åt och vilka sjukdomar och förslitningsskador de led av.

Dessa uppgifter är en del av pusslet när den förhistoriska människans livssituation ska beskrivas. I självförsörjande miljöer som sysslade med födoinsamling och jakt/fiske kan det tänkas om tillgången till byte var rikt och klimatet milt att man arbetade för dagen mer än för morgondagen och att dygnets timmar för vila och fritid var fler än när grupper blev bofasta. Bondekulturen växte sedan fram efterhand och större grupper av människor slöt sig samman i bygemenskap. Dessa människor lagrade utsäde samt höll boskap och hade husdjur i större utsträckning än samlarkulturen som sannolikt var nomadisk och småskalig. Vid brist på vilt, missväxt och ofred var det givetvis kris i alla miljöer. Kanske delades arbetet upp relativt tidigt i vissa befolkningsgrupper och olika arbetsuppgifter kopplades till kön, klass, klan eller släkt/familj. Hantverk som vapentillverkning i sten eller metall, tillverkning av smycken, träsnideri och krukmakeri verkar tidigt engagerat skickliga arbetare, konsthantverkare och smeder. Vissa arbetsuppgifter kanske tidigt ansågs som finare och bättre än andra och värdesystem började växa fram. Inte heller vet vi när lathet skulle tyglas och flitighet belönas i dessa miljöer. Vi vet heller inte när sagor och myter började berättas som handlar om att man genom att arbeta skulle kunna uträtta stordåd. Men någon gång i mänsklighetens begynnelse, innan skriftens uppkomst, började man säkert vid lägerelden eller härden berätta historien om, som det ofta är, den manlige och slugt kreative hjälten. Han som i historiens gryning blev prototypen för en grekisk Herakles (Herkules) en mesopotamisk Gilgamesh eller en indisk Krishna. Ett berättarmotiv som bland annat vill visa att det går att arbeta med framgång och därigenom uträtta stordåd.

Om sumererna i tvåflodslandet, Mesopotamien, landet mellan Eufrat och Tigris för omkring fyra tusen år sedan berättas i det babyloniska skapelseeposet Enuma elish att den upproriske guden Qingu dödas av hjälten och kulturgrundaren Marduk som sedan skapar människan med hjälp av Qingus blod och mylla. Man skulle kunna säga att människan skapas när en ond och oregerlig princip som Qingus blod, blandas med den goda fertila matjorden. Den näringsrika jord som består av det slam som floderna för med sig ut i det bördiga floddeltat. Av denna kreativa blandning formar sedan Marduk människan och ger henne liv. Som det heter i skapelseberättelsen; "Av hans blod skapade han människosläktet lade på dem gudarnas mödor, och gudarna blev befriade". ${ }^{35} \mathrm{M}$ änniskorna ska alltså arbeta och gudarna ska vila. Arbetet är en gåva till gudarna. Människan är helt enkelt skapad för att tjäna gudarna. ${ }^{36}$ Hon är en gudarnas slav.

Ola Wikander kallar det babyloniska folket i sitt förord till översättningen av Enuma elish för "ett slags kosmisk arbetarklass" ${ }^{37}$ Detta är väl uttryckt och betecknar deras primära kultiska roll som gudatjänare och offerfunktionärer i gudarnas tempelboningar. Men folkets vardagliga sysslor som fåraherdar och jordbrukare sågs även det som delar av en gudomlig strategi. Plog och ok var ju också betraktat som gudaskänker från

35 Enuma elish. Det babyloniska skapelseeposet 2005:63 (övers. Ola Wikander).

36 Samuel Noah Kramer 1958:122.

37 Enuma elish. 2005:20 (förord Ola Wikander). 


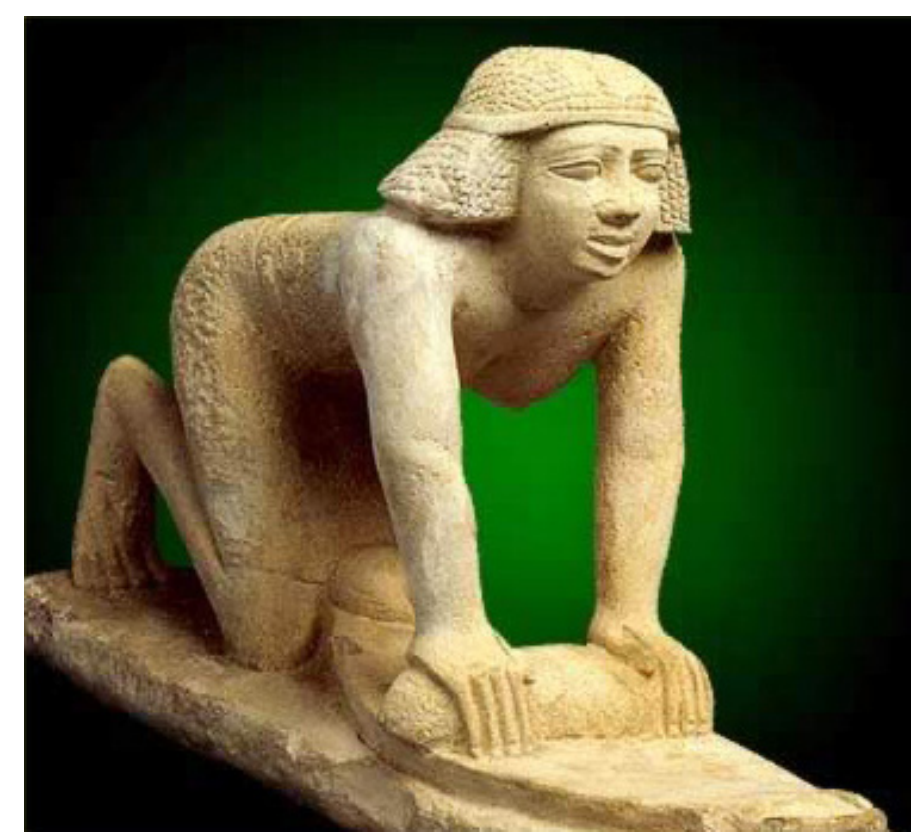

Antik statyett av kvinna som framställer mjöl (www.womeninthebible.net; 2013-06-24).

ovan $^{38}$ I det forntida Babylonien var det alltså en plikt att arbeta och inse sin plats i jordbrukskulturen oavsett om det producerades för föda eller för offer - allt annat vore en hädelse. Det verkar också, som ett ideal, funnits tanken att unga ska arbeta och gamla ska få vila. Detta gäller såväl gudar som människor. Allt har sin tid. De arbetande generationerna kommer och går.

Enligt sumererna styrs världen av mekrafter. Detta me som också är en sysselsättnings innersta väsen. En kreativ energi som finns i själva aktiviteten. ”Det finns tecken som tyder på att det fanns en föreställning om en universell och kosmisk ordning som sedan skulle förverkligas i mänskligt handlande." ${ }^{39}$ De lagar som skrevs var ett uttryck för världens gudomliga ordning. Den rätta inställningen är att frukta gudarna. Gör människan det så är framgång och långt liv människans belöning. Synd är när man vägrar lyda och gör uppror mot gudarna. ${ }^{40}$ En klassisk framgångsteologi således!

I vissa kulturer var själva livsmedlet som odlades heligt. Här kan nämnas majsens betydelse för bland annat mayafolket i nuvarande Mexico. ${ }^{41}$ Människan blir här bunden till grödan på ett rituellt vis så att det närmast uppstår en symbios mellan majs och människa. Majsodlingen bidrar även till att människorna blir bofasta. Att odla majs är ett arbete i gudarnas tjänst. Ett gudomligt arbete! Liknande uppfattning fanns hos aztekerna där de flesta yrkeskategorier hade sin egen gud. Även hos inkafolket i Peru var många arbeten en förpliktelse mot gudarna.

Den fornegyptiska livsuppfattningen är liknande den mesopotamiska. Det gäller att finna sig i sitt öde och följa den större kosmiska ordningen utan att göra för mycket väsen av sig för "Den som räknar alla dagar har aldrig ett lyckligt ögonblick" ${ }^{2}$ Den framgångs-

38 Samuel Noah Kramer 1958:126.

39 Helmer Ringgren 1987:52.

40 Helmer Ringgren 1987:134f, 139.

41 Paul Gendrop 1998:7.

42 Henri Frankfort 1961:68 även Helmer Ringgren 1987: 264ff. 
rike verkar i tysthet utan att skryta och följer "maat" gudarnas och människornas ordning. Tiden är ur led om man inte verkar i harmoni med naturen. ${ }^{43} \mathrm{M}$ änniskan måste underordna sig det högsta värdet, maat och följa den gudomliga viljan som administreras genom kungen/farao. Varje översvämningsperiod har sitt av den gudomliga ordningen fastställda arbete som måste utföras utan knot. Kanaler ska grävas, bevattningssystem byggas, vatten pumpas och mark odlas upp. För att denna kosmiska ordning, maat ska ligga orubblig och Nilen svämma över i rätt tid är Farao en garant. Även här kan skönjas ett tjänarideal. Farao och prästerskapet tjänar gudarna och de arbetande massorna ser genom jordbruksarbete och officiella massarbeten till att ordning och hierarki upprätthålls och att prästerna, den högt uppburna skrivarklassen och regentdynasti kan sköta sin ceremoniella, administrativa och rituella uppgift i lugn och ro. Stabilitet är lika med lycka. Förändring ses som hot. I grunden har vi en optimistisk livsattityd - det finns en gudomlig ordning, anpassar man sig till den så får man framgång både i denna och $\mathrm{i}$ den kommande världen. Även detta är en klassisk framgångsteologi.

Det klassiska kinesiska synsättet har i sin tur likheter med denna egyptiska syn på ordning i tillvaron. Att arbeta med jorden i det gamla Kina och kanske i viss mån fortfarande i folklig uppfattning är att följa "tien tao" (himlens väg) och genom att verka och veta sin plats i tillvaron tjänas det allmänna bästa. Riter utfördes dagligen och stundligen för att främja jordbruket och förfädernas betydelse var stor i det antika Kina. En människa är ingen isolerad individ utan en länk i en samhällskedja som Himmelen själv instiftat. Människans största plikt är att vara en god medmänniska och handla rätt. I idealsamhället som kan skönjas i källorna vet alla sin plats. Samhällsharmoni bygger på att alla visar hsi'ao (sonlig lydnad). Denna lydnad och fromhet anses som grund för all sann religion i det forna Kina. ${ }^{44}$ Enligt fornkinesisk och konfuciansk uppfattning bygger en fungerande hierarki på en känslomässig relation präglad av vördnad. Alla, från kejsare till yngste son och dotter måste veta sin plats och sina plikter gentemot olika individer och mot kollektivet. Varje lantarbetare är en kugge som hjälper till att upprätthålla stabilitet genom sin arbetsinsats. Det finns en tillvarons större rytm och harmoni avspeglad i idén om yin och yang som samverkande olikheter vilka båda behövs för att bilda en fungerande helhet. Du existerar för att du rätt ska utföra din av ordningen givna arbetsuppgift. Detta var en grundläggande inställning som under första hälften av nittonhundratalet sannolikt var viktig för att vinna de kinesiska jordbrukarna för kommunismens sak. Mao var säkert medveten om detta. Vad är egentligen nytt under solen?

Den antika europeiska synen på arbete, och då talar vi om både Grekland och Rom, var att slavar var nödvändiga för att uppnå arbetsbefrielse för den härskande klassen. Det vill säga att köpte man sig en slav så köpte man sig också fri från ett arbete. Under den grekiska antiken var överklassens syn på arbete i stort sett negativ. Ofrivilligt kroppsarbete ansågs likvärdigt med slaveri och fria män arbetar inte med sådant. ${ }^{45}$ Det nygrekiska ordet för arbete är bildat av det antika grekiska ordet för slav. (doulià/arbete av dou-

43 Henri Frankfort 1961: Kap 3 59-87.

44 Bernard Karlgren 1964: 6, 52, 88ff.

45 Miroslaw Volf 1991: 126, Hannah Arendt 1998:123f. 
los/slav). ${ }^{46}$ Det var även skillnad mellan olika slavar och att vara husslav var sannolikt lättare och ansågs bättre än att vara $\mathrm{i}$ arbete på havet som roddare eller verka som slavarbetare i jordbruk och gruvor. Det fanns under antiken i Grekland också en stor grupp av mobila säsongsarbetare inom jordbruket som troligtvis stod lågt på samhällsskalan. Slavar var vanligt i rikemanskretsar och Odysseus hade, om jag inte missminner mig femtio slavinnor. Enligt Homeros var de verkliga yrkena fyra: siaren, sångaren, läkaren och timmermannen. ${ }^{47}$ En hel del av våra nutida yrken skulle sannolikt betraktas som vanhedrande av den antika grekiska överklassen. Krigets arbete eller krigets 'hantverk' var däremot en accepterad sysselsättning. Att arbeta inom och för familjen var också tillåtet och ärbart. Kvinnors arbete hade gudomlig legitimitet, kanske männen ville ha det så, och var de flitiga med att laga mat, karda, spinna, väva och sy så gjorde de allt detta under Pallas Athenas beskydd. Pallas Athena var också en så kallad kulturhero som uppfunnit och gett människorna kunskap om värdefulla ting inom hem och jordbruk. Jungfrugudinnan Athena, var ett gott föredöme för kvinnor i alla fall sett ur ett manligt perspektiv. Hon var kysk, begrep sig på krig och krigföring och slängd i både kök och jordbruk. En veritabel arbetsmyra.

Den romerske poeten Ovidius skriver i sina Metamorfoser att under den så kallade guldåldern gav jorden självmant ifrån sig sina gåvor. ${ }^{48}$ Det krävdes alltså inte någon mänsklig arbetsinsats under den första mytiska urtiden. Det var bättre förr - den inställningen känner vi igen från alla tider. Även Vergilius skriver i Georgica om arbetets mening och värde. Det är en didaktisk dikt om lantbruk som ger ett idealiserande makthavarperspektiv på lantlivets mödor. Männniskan är av gudarna dömda till arbete men bör finna sig i detta utan knot och därtill dyrka gudarna som tack. ${ }^{49}$ De antika romerska filosoferna funderade också över livets korthet och våra problem med att fylla livet med väsentligheter. Emellertid var det nog inte som regel så att filosoferna ansåg att det var arbete som livet borde vara fullt av. Att ha mycket arbete var inte de rikas ideal då framgång enligt deras mått snarare mättes med vilken art och grad av politisk makt man uppnått. Måttet på framgång var graden av makt. Seneca spetsar till saken när han skriver om tiden - "Livet är tillräckligt långt men vi använder den för dåligt. Vi slarvar bort tiden." ${ }^{\prime}{ }^{\circ} \AA$ andra sidan är det ju passiviteten som angrips här. Seneca vill säga att vi borde vara mer aktiva och aktivitet tar sig ju ofta uttryck i någon form utav arbete även om det är politiskt och filosofiskt tankearbete som Seneca avser här. Seneca som företrädde den filosofiska riktning som kallas stoicism menar vidare om yrke att man inte ska värdera människor efter vilket jobb de har utan efter deras karaktär. ${ }^{51}$ Detta leder oss in på det faktum att stoicismen var den mest spridda av de filosofiska riktningarna som fördömde slaveriet som en stor orättvisa i slutet av det andra århundradet..$^{52} \mathrm{M}$ en i

46 Natan Valmin 1937:8.

47 Natan Valmin 1937:20f..

48 Ovidius 1961:19.

49 Vergilius 1989.

50 Seneca (i översättning av Johan Bergman) 1949.17f).

51 Seneca 1969:94.

52 Edith Hamilton 1959:155. 
likhet med andra stora orättvisor var det lättare att bli medveten om den än att i sak bli av med den.

Den filosof som kallas Pseudo-Plutarchos har sagt att livet delats mellan vila och arbete. Tanken på denna balans återkommer hos andra romerska författare. ${ }^{53}$ Insatt i detta resonemang finns ett förhållande mellan ljus och mörker, dag och natt. När det är ljust så arbetar man och när det är mörkt så vilar man. Att utnyttja dagsljuset på bästa sätt från gryning till skymning var målsättningen för människorna i den av el obelysta historien. Det är för övrigt ett magert källmaterial om arbete i antikens Rom, långt mer finns då beskrivet om fritidssysselsättningar. Vi vet dock att det inte var ovanligt att barn började arbeta redan vid sju- åttaårsåldern. Vad de barn som gick i någon form av skola lärde sig om arbete och arbetets mening vet vi inte mycket om. Skriver författare positivt om arbete så är det ofta idealiserande och idylliska jordbruksbeskrivningar. Att tvingas arbeta för sitt uppehälle var föraktat av eliten och det är ju de som ofta lämnat källor efter sig och vars åsikter vi därför kan säga något om. Att arbeta med de sköna konsterna och inte behöva ta betalt ansågs som högtstående. Detta var ett tecken på att man var oberoende och fri. De mest lågtstående yrkena i Rom verkar ha varit de människor som handlade med matvaror och som sysslade med slakt och köttillredning i någon form men även skilda underhållningsyrken som exempelvis dansare stod lågt i kurs. ${ }^{54}$ Vill man se om yrkesstolthet förekommer så finns en bra källgrupp och det är gravmonumentens inskrifter. Där vittnar fortfarande stolta och framgångsrika hantverkare och arbetare som kockar, bagare och guldsmeder om en stark koppling mellan arbete och identitet. Det rör sig då mest om män eftersom arbetande kvinnor i likhet med en senare tid mest återfanns inom olika serviceyrken och inte fått några minnesstenar resta på gravplatsen. ${ }^{.5}$

Det brukar i handböcker om romersk religion ofta citeras det som Cicero har sagt, om att romarna, om de jämförs med andra folk är det mest religiösa i världen. ${ }^{56}$ De rådfrågade om gudarnas fingervisning i stort som i smått. Det var därför, menade de, som de var så framgångsrika. Statlig såväl som privat kult gick i mycket ut på att prognosticera framtiden och avtäcka ödet dess hemligheter för ju mer man visste om framtiden desto bättre förberedd kunde man vara. Det gällde att upprätta en ömsesidig relation med alla gudar och makter för att på så sätt gynna det som man företog sig. Det fanns, verkar det, något som liknade ett pragmatiskt kontrakt mellan gudar och människor, ett fiktivt fördrag som sa att sköter ni ert och ger förutsättningar för framgång så sköter vi människor vårt, offrar och ärar er som sig bör. Den privata huskulten var sannolikt utbredd och hemmets makter måste blidkas liksom åkerbrukets. Larer, penater, maner och andra skyddsfenomen skulle ha sin uppmärksamhet. Offer och andra riter skulle garantera lugn och ro och att arbetet gav god avkastning. Allteftersom nya folk inkorporerades med det romerska väldet så fördes också deras gudar till Rom och godkändes vanligtvis för dyrkan av senaten. Klassisk invandringspolitik. Allt för att gynna nya potentiella

53 Domenic Ingemark/Henrik Gerding/Martine Castoriano 2000:117.

54 Domenic Ingemark et al 2000: 123, $125 \mathrm{f}$.

55 Domenic Ingemark et al 2000:128.

56 Britt-Mari Näsström 2005:41. 
arbetsgrupper och få dem att trivas i stormaktens hägn. Detta 'bilaterala avtal' mellan gudar och människor hade troligtvis stor betydelse för arbetsmoralens upprätthållande.

Källäget för kunskap om våra nordiska förfäders attityder till arbete är inte särskilt ljust. Det vi kan säga något om är de mäktiga ätter och personer som på något sätt lämnat historiska spår efter sig i form av traditioner nedtecknade långt efter det att händelserna inträffat. Det fornskandinaviska samhället omkring år tusen var i mångt och mycket hierarkiskt styrt och uppbyggt. Politiska och sociala skeenden såväl som rena arbetsinsatser byggde på relationer där gåvor ofta spelade stor roll som betalningsmedel. ${ }^{57}$ De isländska sagorna berättar om detta och i sagorna prisas ofta den initiativrike. ${ }^{58}$ Allt ska betalas igen och gåvor kräver gengåvor, "med gengåvor varar vänskapen längst om tiden gör tillräcklig verkan" som det står i Havamal. ${ }^{99}$ Liknande relationer upprätthölls med gudarna genom offer och det var en markant rytm mellan arbetsår och festår. Den fornnordiska inställningen till makterna påminner om den romerska. Gudarna ska alltid ha sitt. Vi ger till gudarna för att de ska ge igen. Ibland är detta formulerat av religionsvetare i den latinska formeln do ut des, som ungefär betyder - jag ger för att du ska ge tillbaks. De fria nordiska böndernas extra arbetskraft var trälar eller slavar och om deras historia och uppfattning tiger mestadels källorna. Men i Grottesången i Den poetiska Eddan berättas om trälinnorna Fenja och Menja som arbetade vid den kungliga kvarnen och kung Frode lät dem inte vila. Även i Sången om Rig i nämnda bok berättas om arbeten i ett bondehemman låt vara ett mytiskt sådant. ${ }^{60}$ Det binds korgar i bast och slöjdas i trä och kvinnor serverar, väver, stärker och snor sina sländor. Pojkar växer upp och kommer till krafter:

oxar tamde han, årder gjorde han,

hus fick han timra, hölador bygga;

han gjorde kärror och plöjde plogen. (Sången om Rig 22)

Enligt den romerske författaren Tacitus var germanernas arbetsmoral låg. Han talar om "den normala germanska lättjan" ${ }^{61} \mathrm{Nu}$ är väl Tacitus som sanningsvittne inte särskilt trovärdig och ögonvittne var han inte men han traderar sannolikt den gängse populära romerska uppfattningen om folken norr om Rhen. Synen på 'den andre' känner vi för övrigt igen från vår egen tid. I Havamal finner vi en annan attityd som i Näsströms översättning lyder:

Den må upp i ottan

Som har ont om folk

Och gå till sitt arbete

Den som sover om morgonen

Missar mycket

Halva rikedomen beror på raskhet (Hvm 59)

57 Om gåvors betydelse se Peter Habbe 2005:187ff.

58 Helmer Ringgren/Åke V Ström 1974:365.

59 Havamal 41 i Collinders översättning.

60 Den poetiska Eddan i översättning av Björn Collinder 1964.

61 Tacitus (tolkning Alf Önnerfors) 1961:kap 45. 
Här angrips lathet och idealet är att en bra karl reder sig själv. ${ }^{62}$ Eftersom texterna härstammar från och riktar sig mot en högreståndskultur får vi tänka oss att de vill mana den gode hövdingen eller kungen att ta saken i egna händer och vara ett gott föredöme för sitt husfolk. Vänder vi oss mot den mytiska världen så är de bästa arbetarna dvärgar, men på grund av sitt hat till gudar och människor är de ovilliga att arbeta för dem, speciellt om de tvingas till det. Ett gott arbete utförs ju som vi vet sällan under tvång. Den person som hade framgång i det som han eller hon företog sig ansågs ha en lyckobringare vid sin sida en hamingja i kvinnoskepnad eller en fylgja i djurskepnad som styrde livet eller ödet i rätt riktning. Ödestron har stor betydelse för både person och släkt och är ödet givet av nornor och andra väsen så är det närmast omöjligt att ändra på. Sådana attityder är nog viktigt för rigiditet även i yrkesvalet. 'Skomakare bli vid din läst', är ett uttryck som passar även för detta samhällssystem.

Berättelsen om Valhall ger en uppfattning om den härskande klassens paradis. I det ideala livet efter detta som skildras där övas vapenlek och dryckesseder och det äts kopiöst med fläskkött utan att något egentligt produktivt arbete behöver utföras. Dock avbryts denna välfärdstillvaro när världens slut, Ragnarök närmar sig och övning i vapenlek avlöses av allvar inför den avgörande slutstriden.

Dvärgar var i fornskandinavisk tanke- och berättelsetradition mytologiska väsen som utförde ett för asar betydelsefullt och konstfärdigt arbete. Ursprungligen var de skapade av arbetsamma maskar i Ymers döda kropp, åtminstone menar Snorre så. De lever sitt liv i berg och under jord. Dvärgar satte standard för smideskonst av svärd, kedjor och spjut och utförde skickligt filigranarbete som resulterade i smycken som åtråddes av både gudar och människor. Att något var dvärgasmitt var en kvalitetsbeteckning. Enligt Snorre så bars också själva himlavalvet upp av fyra dvärgar, ett arbete så gott som något. ${ }^{63}$ Även människor växer genom sitt arbete. I Snorres Edda kan läsas att en man " skall kännemärkas genom sina verk, det han ger eller tar eller gör." "' ${ }_{64}$ "Själver är bästa dräng", med andra ord.

\section{Naturfolk: Exempel från Afrika}

Afrika är en stor kontinent med en mångfald av folkgrupper, traditioner och uppfattningar. Ska, trots detta faktum något generaliserande sägas om synen på arbete där, så är det att $\mathrm{i}$ en klassisk traditionell afrikansk miljö var vanligtvis arbete inget individuellt projekt. Arbete var en kollektiv angelägenhet oavsett om folket levde (arbetade) med jakt, boskapsskötsel eller med jorden. Det finns gott om afrikanska riter som är kopplade till krissituationer vid årstidsväxlingar som exempelvis regnperioder och därmed också till jordbrukssysslor som sådd och skörd. I en kultur där andlighet och religion har stor betydelse är också det rituella agerandet en form av nödvändigt arbete som förbereder individen psykiskt för det kroppsarbete som måste utföras. Den grundläggande afrikanska attityden till kroppsarbete är positiv. Du är förpliktigad att utföra ditt arbete

62 Britt-Mari Näsström 2001:311.

63 Snorres Edda i översättning av Björn Collinder 1970: 37, 41f, $106 f$.

64 Snorres Edda i översättning av Björn Collinder 1970: 104. 
för familjens, släktens och gruppens bästa men också för att upprätthålla den andliga relationen med gudar, andar och förfäder genom produktion av offergåvor och rituell rekvisita. Människor blir genom sitt arbete i samklang med kosmos. Ett exempel är Dogonfolket i Mali där jordbruksarbete enligt uråldriga traditioner utförs enligt en mytisk modell. Fälten plöjs i ett spiralmönster enligt en struktur som går tillbaka till gudarnas agerande vid världens skapelse. ${ }^{65}$ Som en praktiserande traditionell Dogon arbetar du alltså i samklang med en mytisk och gudomlig modell. Människan är en del av ett kollektiv som ytterst omfattar kosmos och samtidigt utgör en länk till evigheten.

Du arbetar för världens fortbestånd i ett ständigt upprepat mönster. Att arbeta blir till en nödvändig kommunikation med det gudomliga. En kommunikation som kan ta sig andra uttryck som när en Asantehantverkare i Ghana offrar en kyckling och låter blodet droppa över sina verktyg för att stärka deras egenskaper. ${ }^{66}$ Även en etniskt mångfacetterad grupp som de yorubatalande folken i Nigeria har en traditionell syn på arbete som en närmast gudomlig aktivitet. Du utför tjänst åt de gudomliga makterna. Denna form av gudstjänst kan vara en offertjänst men det kan även vara att utföra ett jordbruksarbete eller ett hantverk. Din sysselsättning är en socioreligiös förpliktelse. I denna kontext verkar du som en gudarnas anställde tjänsteman och arbetare.$^{67}$ Genom att arbeta plikttroget finns möjlighet att få tillgång till detta livets goda som en förberedelse för livet efter detta. Jag kan erinra mig att en nigeriansk vän och etnisk yoruba en gång sa till mig: "Du är här och arbetar en kort tid men det är himlen som är det rätta hemmet."

\section{Hinduism och buddhism}

Begreppet dharma är ett mångfacetterat begrepp i hinduisk och buddhistisk tankevärld. Detta begrepp innebär bland annat en uppmaning att följa sin egen väg, gå sin egen dharma genom att utföra de handlingar som är kopplade till de möjligheter som finns inom den sociala position individen befinner sig i. Du gör din dharma. Genom att följa detta mönster samlar du god karma på din livsväg och arbetar på, samt gör dig förberedd på moksha, frälsning eller snarare befrielse ut ur återfödelsens kretslopp. Genom att följa sin dharma och utföra goda handlingar så deltar den troende aktivt med att upprätthålla universum. Dharma är på så sätt både ett moraliskt och rituellt beteende och projekt vars syfte är att uppnå inre och yttre harmoni.

Det finns ett hinduiskt ordspråk som säger att 'Work is worship' (Virashaiva proverb). Inom K arma-yoga (att genom handlingar nå gudsförening) är vardagens arbete att betrakta som en meditationsform i sig. Handlingar kan vara religiösa/moraliska handlingar men också praktiska insatser inom ett yrkesarbete. Karmabegreppet kan alltså tolkas som ett etiskt system kopplat till att på bästa sätt utföra sina moraliska och sociala plikter. I klassisk hinduisk uppfattning talas det om olika livsstadier och livsmål. Ett av dessa stadier för mänskligt liv och kanske bland de fyra klassiska stadierna det främsta, är när man bildat familj och har ansvar för en större släktgrupps försörjning. Då är det

65 Benjamin C Ray 1976:133.

66 Noel Q King 1986:67.

67 Roland Hallgren 1988/91:8. 
Bevattningsarbete i Kina.

(www.csupomona.edu; 2013-06-24).

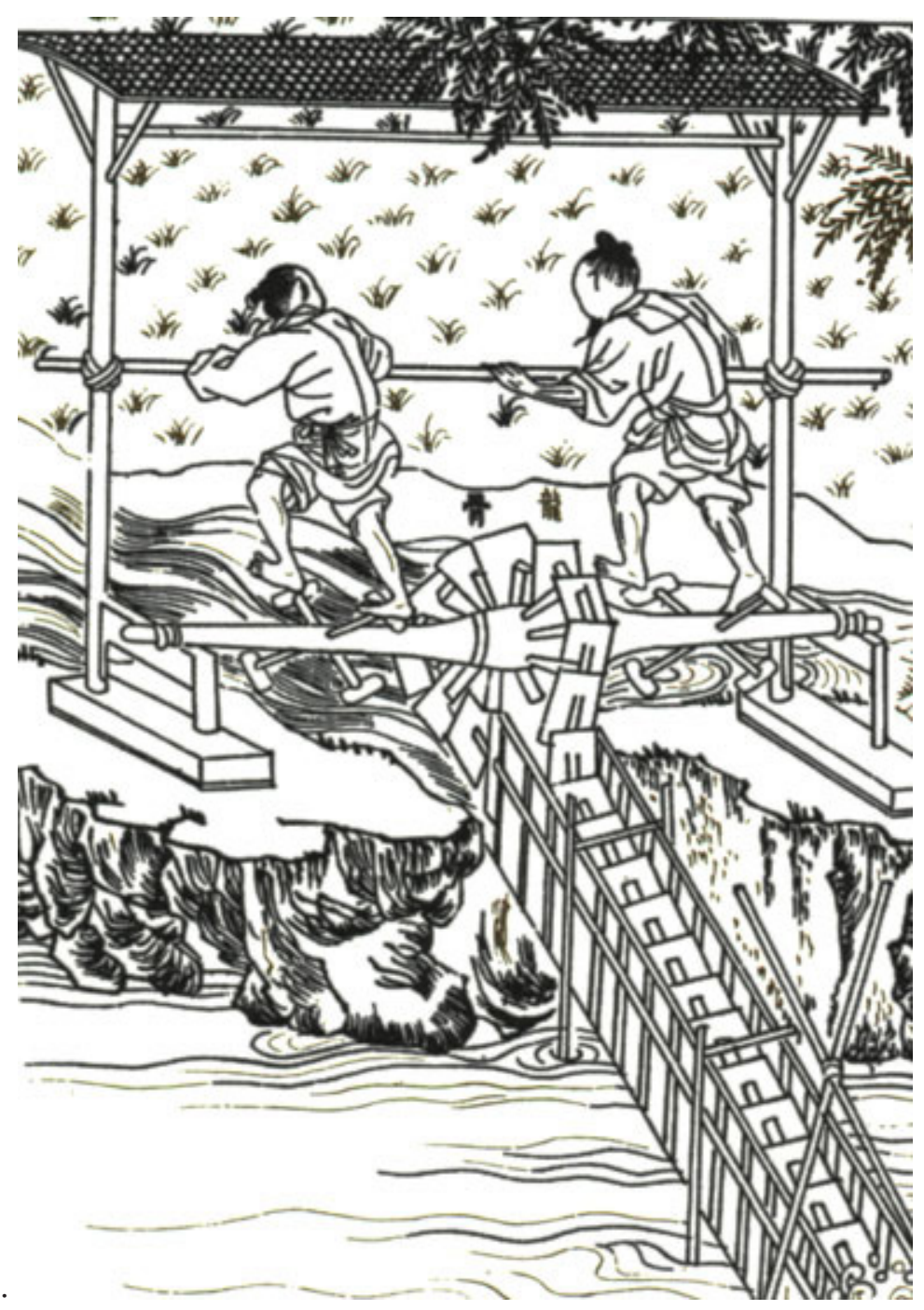

nödvändigt att arbeta träget inte minst för att ekonomiskt förbereda sig och familjen för det sista ideala stadiet då mannen/husfadern ska ta avstånd från allt världsligt. Men detta sista stadie kan endast uppnås om de andra stadierna praktiserats fullt ut. Det finns i hinduisk tanke också en annan kvartett av viktiga värden, de fyra livsmålen. Av dessa är det andra målet, artha, ett klart ekonomiskt mål som kräver aktivt deltagande i det yrke man utbildats till. Sammantaget uppvisar dessa livsideal en positiv inställning till arbete som ett av de stadier som en mänsklig (manlig) individ har att genomgå och en positiv uppskattning av ett av de mål som en människa bör sikta mot i sin utveckling. Livsloppet är en ständig strävan mot att utvecklas till en fullvärdig och nyttig samhällsmedborgare. Det är viktigt att veta att levnadsstadierna beskriver manligt liv, som Jacobsen säger: "Det är obestridligt att hinduismen har lagt betoning på kvinnor som underdåniga hustrur och självuppoffrande mödrar." ${ }_{68}$ Det kan tilläggas att just denna traditionella attityd ofta medför ett ständigt hårt arbete för kvinnor som på detta sätt förverkligar idealbilden av sig själva som barnaföderskor med idogt och tungt hemarbete inom äktenskapets ram.

68 Knut A. Jacobsen 2004:298. Se denna framställning om livsstadier och livsmål. 
Den mest populära och spridda hinduiska texten är sannolikt Bhagavad-Gītā (Den Höges sång) och ingår som en del av det stora eposet Mahābhārata. Gitan berättar om att uppnå det goda genom att handla. Det menas med detta att plikttroget följa sin dharma (väg) som en förutsättning för inre och yttre harmoni. Genom gudshängivenhet och oegennyttig kärlek (bhakti) ska man nå fram till tillvarons mening som är en förening med Gud i Brahmans (alltets) centrum. Slutmålet är att bli ett med Brahman, som närmast är den transcendenta grundvalen för världens uppbyggnad. Texter i Gitan talar uppskattande om vikten av att utföra sin plikt. "Utför den handling som ålagts dig, ty handling är bättre än overksamhet" och "Utför ditt arbete för dess skull, fri från bundenhet." Utför ditt arbete för dess egen skull; "Utför därför ständigt obunden det arbete som åligger dig, ty då hon obunden utför sitt arbete, når en människa det högsta." ${ }^{69}$ Arbete verkar fungera när du utför din syssla oreflekterat i någon slags religiös "flow" Flyt på ett högre plan.

I hinduisk tradition finns också som i de flesta andra kulturer en benägenhet att skilja bättre arbeten från sämre. Att syssla med smuts i olika former (tvätt och renhållning) och slaktrelaterade yrken som garvning och beredning av hudar och läder anses exempelvis som föraktade arbeten som traditionellt utfördes av grupper långt ner i den sociala hierarkin.

Även om buddhismen i likhet med andra religioner finns i olika former både mer officiella, filosofiska och folkliga kan det nog överlag sägas att det är genom utförda goda handlingar som buddhisten förädlar sig själv och befriar sig från egoismens faror. Detta är ett mönster som kan kännas igen både utifrån buddhistiska munkars och nunnors samt lekmännens perspektiv. Samtidigt finns det inom buddhismen uppfattningen att man genom att arbeta fasthänger vid tingen och tillvaron på ett olyckligt sätt som ger upphov till lidande. Denna insikt kan tolkas som att attityden till arbete i grunden är negativ. Snarare är det nog så att det i allmänhet är själva inställningen till arbete som avgör om arbetet ska betraktas som gott eller ont. Att arbeta för andra är ett gott arbete och inte minst är detta oegennyttiga arbete nödvändigt för de som har försörjningsplikt. Det är så att det inom buddhismen finns en slags medkänslans etik där eget arbete utförs för att minska andras lidande. Dalai Lama säger att:

'Det arbete som utförs av en människa med ett oansenligt yrke är inte mindre relevant för samhällets välfärd än det som utförs av exempelvis en läkare, en lärare, en munk eller en nunna. Alla människors ansträngningar är potentiellt storslagna och ädla. Bara man utför sitt arbete med goda motiv och tänker 'Mitt arbete gagnar andra' kan det tjäna samhället som helhet."70

Inom Zen-buddhismen uppskattas moralisk disciplin. Livet är som bäst i den dagliga gärningen, i det tjänande arbetet. Även då arbetar man aktivt för sin upplysning. En zenmästare som hette Pai-chang (749-814) har sagt: "En dag utan arbete - en dag utan mat". Andra menar på samma tema "Inget arbete - ingen mat". Det finns ett positivt

69 Bhagavad-Gītā i översättning av Martin Gansten 2001:44f, 50.

70 Dalai Lama 2000:176. 
uppskattande av fysiskt arbete (samu) inom zen. Samu är ett slag av rörlig zazen (zenmeditation). Det är... "en möjlighet att genom aktivitet stilla och fördjupa sinnet och bringa det till enhet."’ı Arbetar man i rätt sinnestillstånd så är arbetet inte kännetecknat av jäkt och planlöshet, inte ansträngt eller slappt och slösar inte med energi. Allt arbete är egentligen förädlande och ett uttryck för varje individs buddhanatur. ${ }^{12}$

\section{Judendomen och Gamla testamentet}

I Bibelns Gamla testamente (GT) finner vi åtskilliga referenser till arbete. Inledningsvis är det viktigt att påpeka att hebreiska ord för arbete kan ha olika betydelse i skilda sammanhang. Jag förlitar mig i detta avsnitt på definitioner och framställningar i texter, uppslagsverk och diverse handböcker. Det kan finnas problem med ord som betyder möda, tjänst, gärning, verk men även med verbet göra. Sådan översättningsproblematik samt specifik kulturell betydelse är för övrigt ett problem som även gäller andra kulturer jag behandlar i denna berättelse.

Gud placerade människan i Edens lustgård för "att bruka och vårda den" "ᄁз Detta arbete som Guds personlige trädgårdsmästare var sannolikt 'lustfyllt' innan det försämrades på grund av människans synd som får till följd att jorden mer motvilligt lämnar ifrån sig sina gåvor. ${ }^{74}$ Adams ursprungliga roll i paradiset är till en början fritt från att utföra något arbete av förändrande art. Han upprätthåller status quo och framför allt vaktar han Livets träd. Den första människan har närmast en kultisk uppgift och plikt som Guds närmaste tjänare. Synden ska som vi vet från berättelsen om den mytiska tiden snart förändra detta och frukten från Livets träd blir då otillgänglig för all framtid. ${ }^{75}$ I 1 Mosebok 3 kapitlet berättas om tiden efter syndafallet och stölden från kunskapens träd som medför att mannen hädanefter ska hämta näring ur marken, "du skall slita för ditt bröd i ditt anletes svett". I Svenskt Bibliskt Uppslagsverk sägs det följande. "Till följd av syndafallet står arbetet för brödfödan under mödans och osäkerhetens märke". ${ }^{76}$ Detta blev mannens lott. Kvinnans lott blev i stället ett mödosamt födsloarbete. ${ }^{77}$

Vi befinner oss i mytens ursprungliga tid där människorna antingen är herdar eller jordbrukare med hårt kroppsarbete under veckan men har ledigt den sjunde dagen när sabbatsljusen tänds. Då får inget arbete utföras för den dagen är det sabbat och sabbaten är helig och oantastlig. ${ }^{78}$ Motiveringen är att alla människor, även slavar och invandrare ska få hämta krafter för en ny arbetsvecka. Judarna ska också påminnas om att de själva under fångenskapen i Egypten en gång var slavar. ${ }^{79}$ Under sabbaten påminns man om skapelsen men också om domen. Sabbaten är tidlös och omfattar både början och slutet.

\footnotetext{
71 Roshi Philip Kapleau 1995:218 se även 217.

72 Roshi Philip Kapleau 1995:219.

731 Mos 2:15.

74 Gillis Gerleman/Bo Johnson 1972:34.

75 SBU 1962:114ff.

761 Mos 3:19. Se även SBU 1963 II:278.

771 Mos 3:16.

782 Mos 23:12, 3 Mos 23:3.

79 Jfr 5 Mos 5: 13-14.
} 
Det är veckans vändpunkt och en tid för vila och eftertanke. Sabbaten är enligt traditionen vist inrättad av Gud och är ett viktigt judiskt bidrag till världens arbetskultur. Arbetstagaren får här en gudomligt instiftad vilodag och rättighet till arbetsbefrielse. Det uppstår ett förhållande mellan det kroppsliga arbetet under veckan och det andliga arbetet under sabbaten. Människan garanteras genom sabbaten rätten till regelbunden andlig aktivitet. Sabbaten blir en fristad runt vilken de andra dagarna rör sig.

Det finns även i bibeltexten bestämmelser om ett arbetsideal som innebär ett friår vart sjunde år. Ett år då marken ska vila. ${ }^{80}$ Idealet som det syns i texterna eftersträvar ett korrekt förhållande mellan arbete och vila. Det är även Gud som bestämmer helgkalendern och när skördefester och andra jordbruksfester ska firas. Gud ger helt enkelt föreskrifter för ett heligt liv i en helgad tid. Ursprungligen var dock arbetet ett straff för begångna brott. Syndafallet! Arbetet verkar i detta perspektiv vara ett nödvändigt ont. Om arbetet ska betraktas som ett straff som pålagts människan så borde det vara svårt att säga att det samtidigt är gott att arbeta. Finns då det goda arbetet i judisk och gammaltestamentlig biblisk tradition? Innan vi resonerar kring detta ska vi undersöka ett antal bibelställen från Gamla testamentets böcker.

Det är både ett rättvist och ett orättvist arbete som omtalas i bibeltexterna. Det orättvisa arbetet är exempelvis slavarbetet i Egypten där judarna beskylls för att vara lata och enligt sina ägare hellre vill offra till Herren Gud än arbeta för Farao.$^{81}$ Detta dilemma löses genom att Gud lovar att ingripa i skeendet. När det judiska folket senare erövrade Kanaan och besegrade folken som bodde där så drevs de besegrade inte bort men fick utföra "tvångsarbeten" som bibelöversättningen säger. ${ }^{82}$ Också detta må betraktas som ett negativt arbete sett från de besegrades utgångspunkt. Från judiskt perspektiv är detta en del av Guds plan och förbund med sitt egendomsfolk. Ett mer positivt arbete är sådant arbete eller en sådan arbetsinsats som Gud har beställt. Exempelvis byggandet av Guds boning som en förbundsark gjord av akacieträ eller byggandet av ett tempel i Jerusalem. ${ }^{83}$ Det är noggranna föreskrifter som ges i texterna, för det rör sig ju om att följa gudomliga ritningar i överensstämmelse med den heliga arkitektur som Gud har konstruerat och befallt. Konstfulla arbeten av hantverkare står högt i kurs. Allt arbete ska utföras på ett fullgott sätt. Detta sker genom att Gud fyller på arbetstagaren med gudomlig inspiration och förmåga ${ }^{84}$ Människan förmår ingenting utan Guds vilja och kraft. Men den arbetande ska ha skälig lön och den som arbetar ska ha sin lön innan solnedgången. ${ }^{85}$ Arbetsrätten är här instiftad av Gud.

I den kända psaltarpsalmen 104 som är en lovsång till världens skapelse och harmoni så sägs det att; "'Människan går ut till sina sysslor och arbetar tills kvällen kommer."

80 3 Mos: 25.

812 Mos: 5.

82 Dom 1: 28-35.

832 Mos 25: 8-11, 1 Kung 6ff.

842 Mos 31: 3-5, 2 Mos 36: 5.

855 Mos 24:15.

86 Ps 104: 23. 
all denna ordning är god och skapad av Gud precis som när bonden plöjer, harvar och sår. "Hans Gud lär honom rätta sättet, det är han som vägleder honom."

Ordspråksboken, denna skatt av talesätt menar att; "Den som försummar sitt arbete är vandalens like." ${ }_{88}$ Här kan den kritiske läsaren ha synpunkter på valet av ordet "vandal" i översättningssammanhanget eftersom vandalerna knappast uppfattades som ett hot under biblisk tid. Trots detta ordval är avsikten, tror jag, att få läsaren att uppmärksamma skillnaden mellan det konstruktiva, stabila och goda arbetet jämfört med det destruktiva och passiva som likt vandalens arbete aldrig finner sin rätta plats i tillvaron. I ett jordbrukssamhälle som det som existerade under biblisk tid var det en svår synd att vara lat. "Den late plöjer inte om hösten och finner ingenting i skördetiden." ${ }_{99}$ Svälten står då för dörren. "Flit och förutseende ger vinst, hastverk bara förlust." ${ }^{90}$ Den goda hustruns flit hyllas och "långt mer än pärlor är hon värd", hon arbetar med flinka händer redan i gryningen "och hugger i med starka armar" - " må hon prisas i portarna för sina verk." ${ }_{91}$ Detta att prisas i portarna syftar på att hennes man som en bland andra äldste sitter till rådslag och doms på öppna platser i stadsportars närhet som man gjorde i bibelns länder vid denna tid.

Predikaren har en annan och mer kritisk grundinställning och frågar sig; "Vad får människan ut av all sin möda under solen?" "'Tungt är det arbete Gud har lagt på människan. ${ }^{93}$ En pessimistisk attityd förvisso men den ryggar inte tillbaka för det svårbegripliga och tvetydiga i tillvaron. Predikaren inser samtidigt "att det inte finns något gott för människan utom glädjen i arbetet; det är hennes beskärda del." ${ }^{9_{4}}$ Det främsta hotet mot all framgång även i arbetet, är avundsjukan. ${ }^{95} \mathrm{Om}$ avundsjukan som ett mänskligt gissel och en stark historisk drivkraft skulle man kunna säga mycket men det får bli i ett annat sammanhang. En tänkvärd idé som Predikaren hävdar är att "Drömmen föds av mycket arbete, dåraktighet av mycket prat." ${ }^{96}$ Den som arbetar kan förverkliga en dröm vilket pratkvarnen sällan kan. "God är arbetarens sömn, han må äta litet eller mycket, men den rikes överflöd ger honom ingen ro att sova." ${ }^{97}$ Överflöd stryper frihet och kreativitet eftersom all tid då går åt till att vakta det man redan har - lagom med rikedom verkar bäst, men ändå arbeta idogt morgon som kväll..$^{98}$

I det apokryfiska tillägget till Gamla testamentet så kan vi läsa i Jesus Syrak att det är viktigt att avsluta ett arbete samt att tänka kollektivt - man ska inte arbeta endast för sig

\footnotetext{
87 Jes 28: 26 .

88 Ords 18: 9.

89 Ords 20: 4.

90 Ords 21: 5

91 Ords 31: 10ff.

92 Pred 1: 3.

93 Pred 1: 13.

94 Pred 3: 22.

95 Pred 4: 4.

96 Pred 5: 2.

97 Pred 5: 11.

98 Pred 11: 6.
} 
själv. Samtidigt är det viktigt att behålla sitt oberoende och inte hamna i någons händer. ${ }^{99}$ Syrak syftar nog främst i detta sammanhang på tankearbete, för i hans värld var det slavar och tjänare som utförde det mesta av det dagliga kroppsarbetet och sådana ska hållas på plats - "har han inget för händer, vill han ha sin frihet." ${ }_{100}$ Arbete är preventivt och hindrar uppror. Syrak går i genom olika yrkeskategorier och skiljer mellan de som arbetar med sina händer och de som utför ett intellektuellt arbete och finner att "Den lärdes vishet förutsätter riklig fritid;"'101 Det behövs gott om tid för att tänka och reflektera. Bönder, byggmästare, smeder och krukmakare litar på sina händer och "Utan dem kan ingen stad grundas." ${ }_{102}$ Men de sitter inte i stadens råd, ledning eller domstolar. De säkrar det bestående i världen. "Den däremot som lever för den Högstes lag och ägnar sina tankar åt den, han forskar i alla fädernas vishet och studerar ivrigt vad profeterna sagt." ${ }_{103}$ Vishet, klokhet och insikt är för Syrak störst även om allt sammantaget har ett viktigt ändamål, för "Allt vad Herren har skapat är underbart, och allt vad han har befallt sker i rätt tid." ${ }^{104}$ Människans lott är som den är, ständig möda - vad annat kan vi göra än finna oss i det och gilla läget? Det är ändå så enligt Syrak att den som arbetar slipper tigga och leva osjälvständigt på andra. ${ }^{105}$ Det finns en övertygelse om att var och en får sin beskärda del men ingen får något såvitt inte Gud vill det. Det finns i Jesus Syraks bok en positiv inställning till att arbeta så länge som möjligt. Det talas om att hålla fast vid sin uppgift och åldras i sin gärning, "lita på Herren och håll ut i ditt arbete." ${ }_{106}$ Uthållighet är en dygd.

Den chassidiska judendomens syn på arbete hänger nära samman med den judiska människosynen som betraktar människan som en enhet bestående av kropp och ande (själ). De chassidiska fromme och lärde syns dra den slutsatsen att kroppsarbete och tankearbete är lika viktigt. Martin Buber anknyter till detta arbetsideal i en berättelse:

"Själen är ju inte en verklig helhet om den inte också är ens kroppskrafter och kroppens lemmar. Skriftens vers: Allt vad din hand gör skall du göra av hela din kraft, tolkade Baalschem så att det vill säga också människans kroppsliga väsen skall vara med i det hon gör så att hon inte lämnar någonting av sig själv utanför. Den som kan samla sig till en sådan helhet med kropp och själ hans verk blir ett helgjutet verk."107

Den babyloniska Talmud, Qiddushin 29 säger enligt Hartman att "Den som icke lär sin son ett hantverk, beter sig som gjorde han honom till en rövare." ${ }_{108}$ Det är en plikt att arbeta och överföra arbetets traditioner till den kommande generationen. Men arbetet är också uppfostrande. Det är också i överensstämmelse med bibeltraditionen att bedöma

\footnotetext{
99 Syrak 33.

100 Syrak 33: 26.

101 Syrak 38: 24.

102 Syrak 38: 32.

103 Syrak 39: 1.

104 Syrak 39: 16.

105 Syrak 40: 28ff.

106 Syrak 11: 20f.

107 Martin Buber 1993: 41f.

108 Lars Hartman et al 1973: 210.
} 
och då främst jordbruksarbetet som nödvändigt då det är den enda metod som håller hungern på avstånd. "Arbetarens hunger får honom att arbeta, magen låter honom aldrig vila." ${ }^{109}$ Så säger Ordspråksboken.

Synen på arbete och arbetets mening är i det långa tidsperspektiv som bibeltexterna utgör och så vitt jag kan begripa det, ambivalent. Det betraktas och omtalas ömsom i positiva ordalag och ömsom i negativa. Även om jordbruksarbete med allt vad det innebär av fältens och jordens skötsel, boskapens trivsel, vingårdars och olivplanteringars omvårdnad är viktigt och uppskattat så växer det med tiden fram en något mer positiv syn på hantverksyrken. Men från begynnelsen var jordbruket. "I Första Moseboken upplevs förlusten av det ursprungliga paradisiska tillståndet som ett fall ner i jordbrukslandet." I motsats till det bekymmerslösa paradislivet skulle nu åker och motsträvig mark bearbetas genom hårt kroppsarbete. Bibelns arbetsetos växer fram. Detta etos menar att det är nödvändigt att arbeta kroppsligt såväl som andligt. Även ett rituellt/kultiskt arbete som att bygga Jerusalems tempel och förrätta offerplikten är ett arbete för världens harmoni och för sitt eget bästa samtidigt som man arbetar för sin nästa. Genom att utföra dessa handlingar och andra goda gärningar ärar man Gud och helgar Hans namn." ${ }^{\prime \prime}$ Efter arbetsveckans slut kan frukten av arbetet njutas genom sabbatens ledighet.

Även sabbaten är ett sätt att minnas och helga Gud och hans skapelse i en slags imitatio Dei - Gud vilade på sjunde dagen och gjorde den till en helig dag. Därför bör även du då vila från din egen kreativa möda. Det läggs ett arbetsansvar på människans axlar och själva arbetet heliggörs genom att människan i bibeltexterna uppmanas leva så att Gud kan använda sig av sin skapelse. "Why don't you live so God can use you" som det heter i en Negro Spiritual. Det finns även ett framgångskoncept presenterat i Gamla testamentets böcker. Förhållandet mellan arbete och framgång förverkligas bäst genom kontinuerlig god och lydig Gudskontakt. Det lönar sig alltid att arbeta både moraliskt och socialt. Att arbeta är ett uppfostringsprojekt. Resultatet av din möda blir ökat välstånd och hälsa. ${ }^{112}$

Slutsatsen följer att arbetet är precis som människan på ont och gott. Det är eller blir av både god och ond natur - det blir vad vi gör det till $i$ enlighet med vår fria vilja och mänskliga natur. Men arbete är inget vi kan frigöra oss från. Det är ett nödvändigt både gott och ont som tillhör livets yttersta förutsättning. Det finns inom judendomen en positiv uppskattning av själva ansträngningen både när det gäller studier och lärande, liksom vid utövande av andra arbetsuppgifter. Det är såvitt jag kan begripa det närmast av hävd betraktat som en religiös plikt att alltid göra sitt yttersta just för att varje dag är en gåva att förvalta. Varje dag är helig och oersättlig. Studier, exempelvis, betraktas av somliga judar som en form av gudstjänst. Du ska ta vara på din förmåga och din tid på jorden. Slarva inte bort den. Barnens fostran i en positiv arbetsmoral är tydlig. Jag ser det som en tydlig koppling mellan arbete och överlevnad. Den mest uttalat positivt glädjefyllda

109 Ords 16: 26.

110 Karen Armstrong 2005: 46.

111 Bente Groth 2002: 127.

112 Jfr 5 Mos 30: 8-10. 
synen på arbete i judisk tradition finner vi kanske i den chassidiska östeuropeiska kulturen.

\section{Kristendomen och Nya testamentet}

Kristendomen är ingen odelad enhet utan består som de flesta religioner av ett vittomfattande och splittrat fält. Den innehåller flera olika huvudriktningar utvecklade under speciella historiska förutsättningar med relativt stor skillnad i teologisk teori och praxis. Därtill skiljer sig folklig uppfattning många gånger åt från den mer officiella och teologiskt normerande religionen. I detta avsnitt försöker jag för enkelhets skull ändå att se kristendomen som en enhet. Jag ägnar i sammanhanget mest uppmärksamhet åt den lutherska reformationens betydelse för framväxten av arbetsattityder och arbetsmoral. Det är främst texterna i Nya testamentet (NT) som får tala. Tolkningarna är det däremot jag som är ansvarig för.

Det brukar sägas att kristendomen står fast förankrad i en judisk och gammaltestamentlig tradition. Detta blir tydligt även när det gäller den nytestamentliga bibeltextens motivering till arbete samt texternas resonemang om arbetets värde och mening. Låt oss nu se vad evangelierna och Pauli brev säger om arbete.

Matteusevangeliet blev tidigt det mest använda av de fyra evangelierna. I Matteusevangeliet ingår Bergspredikan där Jesus ber åhörarna att inte bekymra sig alltför mycket om det jordiska - Himlens fåglar varken sår eller skördar men blir likväl mätta. Ängens liljor växer utan att vare sig arbeta eller spinna. Det Jesus vill göra är att övertyga lyssnarna om att Guds rike är större än människornas. Sök först Gud och hans rättfärdighet "så skall ni få allt det andra också." ${ }_{133}$ Tro, lev och verka i nuet är budskapet.

Jesus synsätt handlar också om att människorna är alltför inriktade på det jordiska och det speglas i utsagor som; "Arbeta inte för den föda som är förgänglig utan för den föda som består och skänker evigt liv och som Människosonen skall ge er." ${ }^{114}$ Vad Jesus kritiserar här är bristen på andlighet och tro. Det finns ett bröd som är mer näringsrikt och som är en förutsättning för världens liv. Det är Guds bröd. ${ }^{115}$ Tro och tjäna är nyckelorden. Människan ska också genom sitt arbete tjäna sin nästa. "Den som vill vara stor bland er skall vara de andras tjänare, och den som vill vara den förste bland er skall vara de andras slav." ${ }^{116}$ Så säger Jesus enligt Matteus i en konfliktsituation med lärjungar angående den främsta platsen i himmelriket. Det tjänande arbetet är annars ofta en kvinnlig angelägenhet som när systrarna Marta och Maria passar upp Jesus hemma hos den uppväckte Lasaros med mat och smörjelse sex dagar före den judiska påsken i Betania..117 Fast ännu större än det tjänande arbetet verkar kunskapssökandet vara som när Maria lyssnar, stilla sittande vid Jesus fötter. ${ }^{118}$ Den aktiva Marta bekymrar sig om mycket men

\footnotetext{
113 Matt 6: 26-34.

114 Joh 6: 27.

115 Luk 6: 33.

116 Matt 20: 26f.

117 Joh 12.

118 Luk 10: 38-42.
} 
Maria har enligt Jesus gjort det rätta kontemplativa valet. Budskapet som Jesus kommer med är trots sin ibland tydliga livsfrånvändhet inte någon passivitetsuppmaning. Jesus som själv är jude har den judiska synen inte bara på kunskapsinhämtande utan också på förhållandet mellan sabbat och arbete och säger enligt Lukas; ’Det finns sex dagar då man skall arbeta." "119

Ett bibelställe där Matteus tar upp arbete är Jesu liknelse om Vingårdsarbetarens lön. Daglönearbetaren ska ha skäligt betalt och det är naturligt att arbeta om arbete finns att få; "Varför står ni här hela dagen utan att arbeta?" - frågar jordägaren i berättelsen "Därför att ingen har lejt oss." - svarar de arbetslösa. ${ }^{20}$ Vad som är den "rätta" lönen kan diskuteras men regeln gäller att arbetaren alltid är värd sin lön. Så menar också Paulus i Första Timotheosbrevet antagligen refererande till vad Lukas säger, men också till det som står i GT om att oxen inte ska nekas mat när han arbetar med den betungande tröskningen. ${ }^{121}$

När Paulus skriver till församlingen i Korinth att "var och en skall få lön efter sitt arbete" så menar han säkert att arbetaren är värd sin lön även om utsagan används för att förklara att det är Gud som ger förutsättningarna och människan är att betrakta som Guds kreativa medhjälpare. ${ }^{122}$ Församlingsmedlemmarna uppmanas att sluta träta och acceptera att de är som Guds egen åker redo för sådd i Kristi namn. Människan är Guds verk och bygge som måste arbeta hårt med sina egna händer för att försörja sig. ${ }^{123}$ Den som står fast och orubblig och hängivet ger ut av sig själv i arbetet för Gud får sin belöning; "Ni vet ju att han inte låter er möda vara förspilld." ${ }_{124}$ I dessa Pauli brev rör sig ju arbetsinsatsen naturligt nog om att arbeta för Guds rikes ankomst. Det är ett missions- och frälsningsarbete i Jesu namn. Detta arbete utförs av var och en efter förmåga. Resultatet ska svara mot den goda viljan. Du duger som du är. "Har någon bara den goda viljan, så är han välkommen med vad han har och bedöms inte efter vad han inte har." ${ }_{125}$ I församlingen eftersträvas jämvikt och det eventuella överflödet ska fördelas rättvist. ${ }^{126}$ Inte för mycket till den som har mycket och inte för lite till den som inget har. Det goda arbetet sker i Jesu namn och efterföljd. Låt kärleken råda och utför allt verk helhjärtat. Men det paradoxala var att romarriket under denna tid till stor del var ett slavsamhälle där lydnad för de jordiska herrarna var normen men samtidigt visar alltså attityderna på förtröstan och sann Gudsfruktan. ${ }^{127}$

Paulus uppmanar församlingen i Thessalonike sålunda; "Sätt en ära i att leva lugnt och stilla, sköta ert eget och arbeta med era händer så som vi har föreskrivit er." ${ }^{128}$ Lever man

119 Luk 13: 14.

120 Matt 20: 6-7.

1211 Tim 5: 18, Luk 10: 7, 5 Mos 25: 4.

122 1 Kor 3: 8.

123 1 Kor 4: 12.

1241 Kor 15: 58.

1252 Kor 8: 10-12.

126 Kor 8: 13-15.

127 Kol 3: 22.

1281 Thess 4: 11. 
så får man aktning och blir oberoende. Sällan slås väl arbetets relation till jordisk överlevnad fast hårdare än i Andra Thessalonikerbrevet; "När vi kom till er gav vi er som föreskrift: den som inte vill arbeta får inte heller äta." Att arbeta är nödvändigt för själva världsordningen kräver detta - "arbeta lugnt och stilla och äta sitt eget bröd." ${ }_{129}$ Det slås också fast att den som inte fattar detta bör uppfostras och talas tillrätta. ${ }^{130}$

Jesus hade troligen samma yrke som sin jordiske fader Josef och var alltså timmerman eller snickare. Det var vanligt att yrken gick i arv inom familjen. Jesus lämnar ju sedan detta arbete för sin frälsningsuppgift och kallar även andra att också lämna sina arbeten för att bli hans lärjungar. Det finns i texterna jag studerat en mer eskatologisk och pneumatologisk syn på arbetet än man från början kan tro. Det är således Andens kraft som styr arbetet mot frälsning och paradis. Även om tiderna är mörka så kan världen förändras etiskt genom att människan samarbetar med Guds vilja. Detta sker som jag förstår det genom exempelvis ett intensivt missionsarbete. Där kan Paulus betraktas som ett lydigt Guds verktyg och arbetsetiskt föredöme. Guds ande görs verksam i själva arbetsprocessen och arbetet blir karismatiskt och ändamålsenligt. Detta kan utsträckas till att omfatta omsorgens arbete som det skildras i vissa bibelverser. Både världen och du själv kan förändras genom att arbete utförs för andra. Alltså ett gott kärleksfullt arbete utförs alltid för ett högre syfte och andras bästa och inte bara som ett arbete i individuellt självintresse. Att förverkliga sig själv genom sitt arbete är inget krav som Gud ställer. Det främsta arbetet är oegennyttigt och där är också bön och gudsdyrkan en form av Gudi behaglig arbetstjänst och en insats för mänskligheten - ora et labora - bed och arbeta" som det heter i kristen klostertradition. Fattigdom - kyskhet - lydnad och arbete var också vanliga munklöften.

Trots denna uppfattning menar jag att det såväl i Nya som i Gamla testamentet finns en i huvudsak ambivalent syn på arbete - det pendlar mellan att se arbete som ett nödvändigt ont och samhällets behov av flit och arbetsamhet. Det fanns på Jesu tid en uppfattning om en skillnad mellan aktade och föraktade yrken. Aktade yrken var sådana som var förknippade med jordbruk i vid bemärkelse samt ärlig köpenskap och de flesta hantverk. Yrken med mindre värde var sådana som kopplades till oärlighet och osedlighet samt hanterandet av illaluktande och smutsiga ämnen. Även herdar och sådana som tog upp skatt och tull hade låg status. ${ }^{131}$ Någon mer utvecklad syn på arbete som ett moraliskt projekt eller arbetsetik finns inte i NT. Det finns inte några specifika Jesusord om arbetets betydelse eller om relationen mellan människa och arbete. Fast sedvänjan att lära sig sin faders arbete är ju också en form av arbetsplikt och uppfostran. Samtidigt är det så att tanken på den snara frälsning och väntan på Jesu återkomst och det nyetablerade paradiset som var spridd i den tidiga kristendomen inte direkt inbjuder till en massiv och oreflekterad arbetsinsats. Tillbaka till paradiset innebär ju också, så vitt jag kan begripa det, tillbaka till ett tillstånd av permanent arbetslöshet eller arbetsbefrielse från jordiska uppgifter som vi känner dem. Men under jordelivet ska människan inte

1292 Thess 3: 10-12.

1302 Thess 3: 15.

131 Lars Hartman et al 1973: 209f. 
vara overksam och speciellt inte i förhållande till sin nästa. Genom att följa sitt kall gör den kristne sin nästa en viktig tjänst. Det mest triviala yrkesarbete blir då till en kristlig kärlekstjänst. ${ }^{132}$ Arbetet är ändå en plikt som för de herdar som först uppvaktade Jesusbarnet efter födelsen och sedan skyndsamt och plikttroget vände åter till sin fårhjord för att sköta sin syssla. ${ }^{133}$

\section{Luther - Katekes och protestantism}

Det brukar sägas och oftast med hänvisning till den tyske sociologen och filosofen Max Weber (1864-1920) att det finns ett förhållande mellan den protestantiska kristendomstolkningen i Västeuropa och framväxten av kapitalismen som idé. Kristendomen eller snarare den protestantiska etiken och då främst i den kalvinistiska och mer puritanska tappningen skulle då främja ett strävsamt liv utan några krav på extravaganser och uppmana människor till att utan knot utföra sin gärning i det allmännas tjänst, spara och ackumulera kapital för att sedan investera detta i nya kreativa företag. Denna religionens sociala roll var enligt Weber inte oviktig för det västeuropeiska samhällets positiva ekonomiska utveckling. I detta sammanhang är den kristna kallelsens idé viktig. Med detta menas den inställningen att alla människor har en kallelse att utföra en uppgift och en plikt att fullfölja denna kallelse. Kallelsen innebär också att varje individ ska göra sitt yttersta i sitt arbete som en del av Guds stora plan med mänskligheten För att travestera ett känt yttrande. Fråga dig alltså inte vad Gud kan göra för dig utan vad Du kan göra för Gud. Lev ditt liv på ett sätt så att Gud kan ha användning för dig. Enligt Roland Bainton med referens till Martin Luther så gällde den gudomliga kallelsen alla "hederliga sysselsättningar" för "Gud har kallat människan till att arbeta medan han själv arbetar". ${ }^{134}$ Att imitera eller härma Gud och Kristus verkar kunna betyda att både arbeta efter kallelsen i världen som Luther tycks mena eller som augustinmunken Thomas a Kempis (1379/1380-1471) menar i sin uppbyggelsebok De imitatione Christi (Om Kristi efterföljelse) att leva ett världsfrånvänt och asketiskt liv och bära sitt eget kors på samma sätt som Jesus bar sitt. Två vägar mot samma mål som kanske inte är så oskiljaktiga som man först kan tro. Luther hade även enligt Bainton synpunkter på det intellektuella arbetet eller tankens arbete och säger; "Vad det gäller undervisning är det så ansträngande att ingen borde syssla med det för mer än tio år". ${ }^{135}$ Som gammal lärare är jag böjd att instämma.

I ett sammanfattande och klargörande avsnitt i sin bok Krisbiografier skriver sociologen Ulf Drugge att livets mening för Luther inte bestod i att arbeta. Att känna arbetsglädje blir närmast suspekt sett ur ett kapitalackumulerande perspektiv. Snarare är det så att ett mödosamt arbete är nödvändigt för att överleva och hindrar utvecklandet av lättja och girighet. På så sätt stämmer inte Max Webers idé om kopplingen mellan den protestantiska etiken och kapitalismens anda. Arbetet är en plikt och du ska arbeta i tron.

132 Alexander Radler 1995: 148f.

133 Luk 2: 15-20.

134 Roland H. Bainton 1960: 201.

135 Roland H. Bainton 1960: 203. 


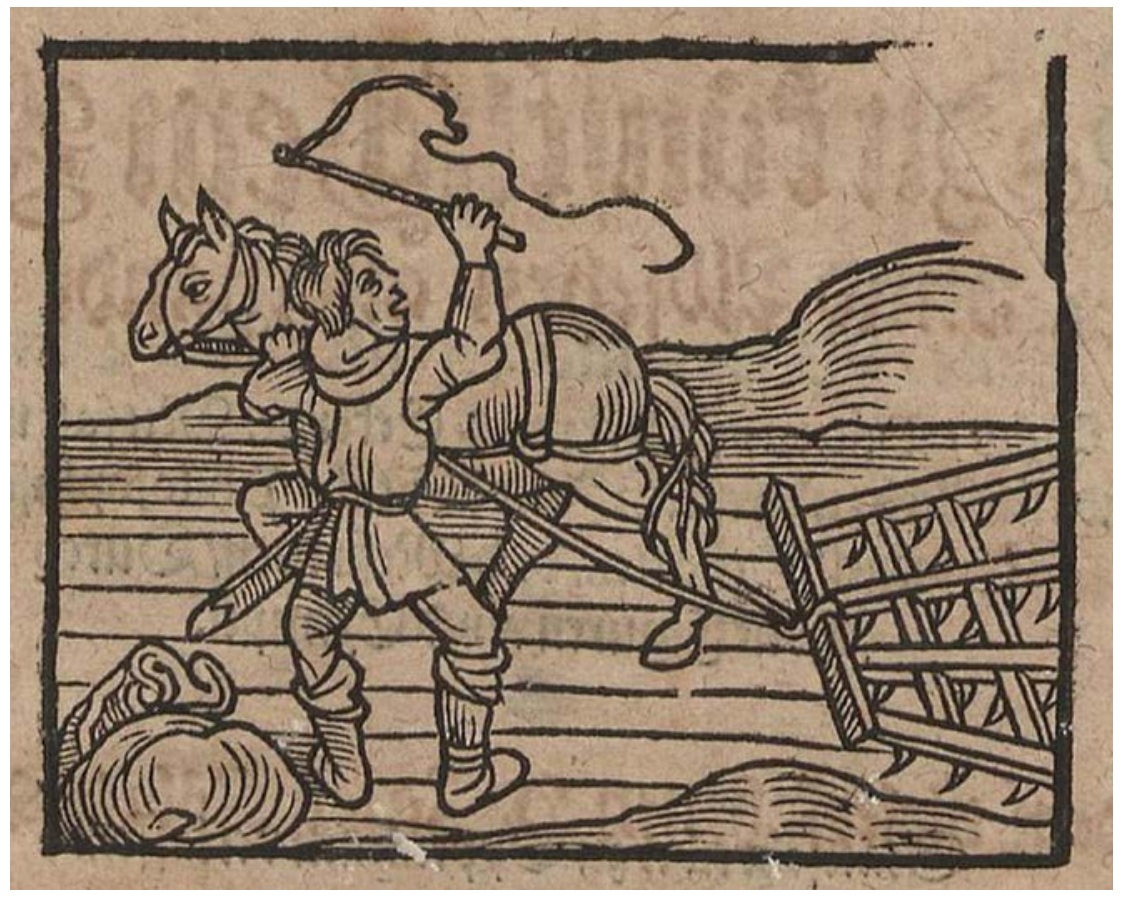

Akern harvas. "Ackerbau", träsnitt av Jacob Koebel (från www. deutschefotothek.de; 2013-06-24).

Arbetet blir ett kall och det faller sig då naturligt att hjälpa fattiga och nödlidande. Människan fortsätter Guds skapelseverk genom sitt arbete. Carl-Henrik Grenholm ser bland annat detta när han analyserar Luthers kallelselära. Denna lydnad inför Guds ögon är ett viktigt Lutherskt incitament för att utföra och känna sig nöjd efter ett gott dagsverke. ${ }^{136}$ Du har gjort din plikt.

Vad står det då om arbete i den en gång i Sverige så spridda och välkända Martin Luthers Lilla Katekes med kort utveckling. Utläggningen av fjärde budet om att hedra sin fader och sin moder slår fast att detta samtidigt innebär att "tjäna dem". ${ }^{137}$ Tjäna föräldrarna i det bondesamhälle där katekesen hade sin största spridning och publik borde nog främst betyda att tjäna dem genom att hjälpa till i självhushållet och med jordbruksarbete i allmänhet. Människan är ju Guds egen skapelse som kontinuerligt ska delta i skapelsegärningen men det är Gud som upprätthåller själva skapelseverket genom sin "nåd och faderliga godhet", utan att människan egentligen förtjänar det. ${ }^{138}$ Vilodagen skall helgas men "Sex dagar skall du arbeta och förätta alla dina sysslor;", innan du på den sjunde dagen vilar från jordiskt arbete och tillsammans med församlingen söker uppbyggelse i Guds ord och sakrament. ${ }^{139}$ Visst arbete får dock utföras på vilodagen om det inte kan uppskjutas. Det är sådant arbete som "kristlig kärlek fordrar". För sabbaten är gjord för människan och inte tvärtom. Så vad gott är, är lovligt att göra. Exempelvis menar Luther att "Jesus gillade, att man på sabbaten gav människor och djur föda samt räddade dem ur livsfara." ${ }^{140}$

\footnotetext{
136 Ulf Drugge 2007: 51ff, Grenholm 1988/1994.

137 Martin Luthers lilla katekes: 4 (Femtonde upplagan).

138 Martin Luthers lilla katekes: 7.

139 Martin Luthers lilla katekes: 30f.

140 Martin Luthers lilla katekes: 33f.
} 
Katekesens anvisningar är anpassade för jordbruksmiljöer och motiveras med lämpliga evangeliereferenser. I sjunde budet som handlar om att inte stjäla så befaller Gud även underförstått "att vi skola vara arbetsamma", och det noteras av Luther att även "Paulus skaffade sig sitt uppehälle genom sitt arbete samt förmanade tessalonikerna att arbeta med stillhet och äta sitt eget bröd." ${ }_{141}$ Denne "hedningarnas apostel" hade som brukligt var även bland laglärde ett yrke, nämligen tältmakarens. För Paulus var det viktigt att kunna skaffa sig sitt uppehälle med hjälp av sina egna händer. I nionde budet sägs det att man inte ska längta efter andras ägodelar utan vi ska "vara nöjda med vår del". ${ }^{142}$ Förnöjsamhet är en dygd även om vi alltid måste vara beredda att bekämpa "det medfödda fördärvet i vår natur" som vill hindra oss från att göra det goda. ${ }^{143}$ Guds omsorg om människan visar sig genom Guds försyn. Guds försyn hjälper oss när vi är trogna "vårt kall". Att vara trogen sitt kall innebär att arbeta idogt. För den som inte vill arbeta skall inte heller äta. ${ }^{144}$ Arbetsmoralen är uttalad i den lilla katekesen som med frikostig användning av bibelcitat slår fast arbetets stora vikt och nödvändighet.

En bok som tar upp arbetets värde ur ett kristet, svenskt och lutherskt perspektiv är Arbetets värde. I denna studiebok i kristen arbetsetik skriver Bengt O. Myrgård, Sigge Niwong och Bo Nylund under redaktion av Carl-Henrik Grenholm med målsättning att stimulera till att bearbeta arbetslivsfrågor på församlingsnivå samt inspirera församlingarna till konkreta insatser i avsikt att upprätta arbetets värde. ${ }^{145}$ Boken från 1977 är författad och utgiven av en redaktionskommitté som är tillsatt av Svenska kyrkans centralråds arbetsgrupp för Kyrkans samhällsansvar, som det heter på bokomslaget. Boken utgår från perspektivet att människan är Guds medarbetare i det ständigt pågående skapelseverket. I det arbetet förverkligar hon sig som en skapande varelse vilket betyder att arbetet har ett högt värde i kristen tro och tradition. ${ }^{146}$ Boken har en integrerad studieplan upplagd på så sätt att varje kapitel lämpar sig för en sammankomst och efterföljande diskussion av de frågor som finns efter varje avsnitt. Boken ger även utrymme för studiebesök. Någon liknande bok har jag inte träffat på i min undersökning men vilken spridning den fick i det konkreta församlingsarbetet under slutet av sjuttiotalet vet jag inte.

\section{Psalm och bön}

Psalm 183 i Den svenska Psalmboken från 1986 "Som sådden förnimmer Guds välbehag i fattig och stenig mull” av B. E. Nyström (1936) verkar som gjord för småländska markförhållanden. I den prisas Gud för mödans skull. Högst tveksamt och först efter hårt arbete ger marken ifrån sig av sin rika gröda. Sedan när helgen kommer "Så lär mig, o Herre, att tro, att helga mitt verk åt din kärleks sak och glömma mitt eget liv. Den

141 Martin Luthers lilla katekes: 46.

142 Martin Luthers lilla katekes: 50.

143 Martin Luthers lilla katekes: 53.

144 Martin Luthers lilla katekes: 64f.

145 Carl-Henrik Grenholm 1977: 10f.

146 Carl-Henrik Grenholm 1977:7. 
bördas tyngd som gör ryggen rak, du skördarnas Herre, mig giv.” Konklusionen blir att du arbetar i ditt anletes svett för en högre sak. Arbetet förädlar och gör dig till en viktig medarbetare i skapelseverket. Eller som Britt G. Hallqvist (1973) skaldar i psalm 182 vers 2-3.

"En dag som andra

då klockan tickar

om knog och jäkt

En dag att leva,

en nådegåva

som Gud oss räckt

På väg till verkstad

fabrik och skola

vi får ett bud

att vi skall tjäna

varann och dela

vårt bröd från Gud."

Varje dag är en gåva från Gud att använda sig av på bästa sätt i tjänst för sin nästa och i gemenskap med Gud. Hallqvist är också involverad i psalm 291 vers 2 där tro och arbete (handling) och nästakärlek hör samman;

"Hjälp oss att vadhelst vi verka

tjäna dig, men ock varann,

att tillsammans enigt stärka

det som bäst oss gagna kan.”

Tålamod är en dygd som i Psalm 283; " Med Jesus fram genom arbetsmödan, de många dagarna utan lön, den tid du bidar den sena grödan, de väntans år utan svar på bön,’. En bondepsalm av J. A. Eklund (1909) lämplig för den alltid åt naturkrafterna så utlämnade jordbrukaren.

Arbetet är självt en gudstjänst, en frigörande kraft som i psalm 290; (Ch. Wesley och bearbetad A. Widegård 1979):

"Gör all min gärning

till en tjänst

med liv och mening i.

När mödan tynger ner min kropp,

gör mig i anden fri."

Frostenson (1965), 499:

"Timmarna i möda, hets och rusningstid tillhör dig - ej bara tyst och ensam tid" 
Dagen betyder arbete; "Oss dagen möda ger och slit. Det får vi alla märka." Natten är vila; "Men natten skänker ro och frid och trötta kroppar stärkas." Efter att tåligt burit arbetets börda i tjänst åt herren så är det eviga livet belöningen (Psalm 501. Dansk folkvisa bearbetad av A. Frostenson 1976. Jfr psalm 554 v 4). Arbetet är mödosamt men "Verka tills natten kommer, kallelsens verk är stort: hela livet behöves, dagarna svinner fort" (Psalm 585, I. Coghill 1854/S. Dahlquist 1913).

"Välsigna, Gud, vår arbetsdag

låt rätt och sanning tryggas, och låt med frihet, vett och lag vårt verk på jorden byggas.

Och led oss alltid, Amen.” (Psalm 594 v 2 K. G. Hildebrand 1984)

Det finns böner för arbete och mot arbetslöshet i Den dagliga andaktens böner i Den svenska psalmboken. "Vi tackar dig, Gud, för vårt dagliga arbete. Låt oss förstå att vi inte arbetar för oss själva, utan för hela den värld du har skapat." (Nr 8) Dagen välsignas, "dess plikter och arbete, dess vila och glädje. Välsigna mina händers arbete..." (Nr 14) Gud tackas för arbete och fostrande prövningar. ( $\mathrm{Nr} 17$ )

"Käre Fader, giv att vi omsorgsfullt

sköter vårt arbete och tar på allvar vårt ansvar för varandras liv och välfärd." (Ur Nr 51)

Nr 107 är en bön vid en vanlig arbetsdag;

"Tack, gode Gud, för mitt dagliga

arbete. Tack för att jag har det, och för att jag orkar med det. Tack för att jag făr vara med och ge andra människor deras dagliga bröd, och för att mitt eget bröd kommer till mig genom andra människors arbete. Vi hör så nära samman, vi lever av varandras kraft."

Vi arbetar i oegennyttig solidaritet i det allmännas och Guds tjänst;

"Jag tackar dig för att också mitt eget arbete får flyta in i denna stora ström av liv och rinna ut till många, som jag aldrig får se."

Det finns böner om kraft att orka med dagens arbete och böner om att inte behöva känna sig övergiven när allt går emot en i det dagliga slitet (Nr 108 och 121). 
En annan källa till arbetets betydelse i den kristnes vardag är Oremus. (Svensk katolsk bönbok utgiven av Katolska liturgiska nämnden 1991). Med utgångspunkt i den betraktelse som kallas "Jesu fördolda liv i Nasaret" (176) talas det om Jesus i Galiléen; "Där lever du i trettio år, upptagen av kampen för det dagliga brödet" - "Han gav upp allt och antog en tjänares gestalt." Livet i Nasaret beskrivs (177);

"Det förflyter under vardagligt, enformigt och hårt arbete. Du arbetar inte bara en dag eller för nöjes skull, utan under större delen av ditt liv vill du dela deras lott som måste arbeta i sitt anletes svett för att kunna överleva. Du känner utmattning och tomhet i din egen kropp, du făr smaka den bitterhet som hör till människans villkor på jorden. Detta gör du av kärlek till de miljoner och åter miljoner bröder och systrar som långsamt slits ut under en övermäktig arbetsbörda. För att kunna visa oss din kärlek går du in under våra villkor, för att med ditt liv och arbete helga vårt liv och arbete, förvandla dess förbannelse till välsignelse och med din utblottelse uppenbara meningen med all mänsklig strävan."

En uttolkning är att Jesus av kärlek identifierar sig med människans villkor. Han bär våra bördor och tar på sig det ställföreträdande lidandets arbete. Det tunga arbete som kan förandliga dig i tjänst för Gud, Skapelsen och Nästan. "Kom till mig, alla ni som är tyngda av bördor. Jag skall skänka er vila." Texten fortsätter med en bön;

" Låt oss be. Gud, välsigna vårt dagliga arbete genom det tunga arbete som din Son utförde. Ge oss kraft och livsmod när vi försöker att göra det som måste göras. Låt oss se vårt eget arbete som ett deltagande i din fortgående skapelse, i Sonens återlösning av världen och som en tjänst åt medmänniskorna. Hjälp oss att tåligt bära den ofrånkomliga tyngden utan bitterhet eller uppgivelse, och låt oss få känna skapandets glädje. Om detta ber vi genom Jesus Kristus, din Tjänare, som kom för att göra din vilja och nu lever och råder i evighet. Amen."

Arbetet tillhör livet och blir uthärdligt först i ett evighetsperspektiv. I ett kristet perspektiv lever du inte för dagen utan för evigheten.

Alla har en uppgift att fylla och att begripa detta är en nåd att be om (178); "Gud, ge oss nåden att inse vikten av vår uppgift i världen, så att vi väl utför det vi är satta att göra." Du måste vara ödmjuk och rättvis. Glöm aldrig att du genom ditt arbete tjänar Kristus själv. Bönen fortsätter;

"Låt oss med ett levande exempel genomsyra andan på vår arbetsplats, så att motsättningar löses i rättvisa och kärlek, med allas väl för ögonen och inte med ömsesidig misstanke och illvilja. Lär oss inse varje människas värdighet och värde i dina ögon. Gör vårt liv till en välsignelse från Jesus Kristus, som inte sökte egen fördel utan endast din vilja och som nu lever och råder i evighet. Amen."

Jesus utförde Faderns vilja och bönerna vill att du som läsare ska ha samma tillit och vara fri och oberoende. Om Jesus sägs det (179); "Du blev aldrig arbetets slav." När den rätta tiden kom så kunde Jesus "utan tvekan och dröjsmål följa din nya kallelse." Den jordiska uppgiften måste tas på allvar; "Låt det samhälle vi bygger på jorden bli en förberedelse för ditt himmelska Jerusalem." Det jordiska arbetet har ett eskatologiskt 
mål. Vi hjälper alla till att etablera den yttersta dagens paradis. Kan arbetet bli mer meningsfullt och framtidsinriktat? För att använda populära termer så är du som kristen medarbetare involverad i det ultimata entreprenörskapet.

Det finns också en särskild bön för industriarbetet (343); "Fader, du kallar män och kvinnor att genom sitt arbete dag för dag ta del i ditt skapelseverk." Alla kan, om vi vill det, skapa en medmänsklig och rättvis värld; "där var och en kan finna ett arbete som motsvarar hans mänskliga värdighet och gudomliga kallelse." Vad du gör av ditt liv är inte betydelselöst eller en slump. Alla har en viktig uppgift. En bön (395) från Bönboken Oremus speciellt tillägnad Arbetet får avsluta denna genomgång av attityder till arbetet i kristna psalmer och böner;

"Herre, gode Fader i himmelen. Du har kallat mig till din medarbetare. Med mitt dagliga arbete skall jag gestalta min del av din stora värld. Tack för ditt förtroende, tack för de talanger och möjligheter som du gett mig. Låt mig nu få tjäna dig varje dag med hängivet arbete, med hjälpsamhet, förståelse och uppmuntran. Låt mig på min arbetsplats få vara någon till hjälp med gott humör, uppmärksam blick och förlösande ord, så att missförstånd röjs ur vägen, misstron övervinns, samförståndet bevaras. Låt mig så lämna mitt bidrag till en bättre värld. Gör mitt liv till en lovsång som får sin fulländning i dig.”

Som Guds arbetskamrat gör du alltid ditt bästa efter de förutsättningar du har men du har också ett socialt ansvar för att i arbetet vara en god medmänniska. Detta är ditt bidrag till en bättre värld.

\section{Islam}

En grundläggande islamisk uppfattning är att människan skall vara aktiv i världen och tjäna skapelsens Herre som uppenbarat sitt ord för människorna genom profeten och sändebudet Muhammed. Människan har genom skapelsen fătt ett förnuft att använda när hon studerar världen och genom detta förnuft blir det möjligt att tolka Guds tecken i skapelsen. I Koranen sägs så vitt jag kan finna det inte i klartext att människan skall vara en arbetande individ. Men uppfattningen att människan ska lära känna skapelsen innebär också den tjänande plikten att genom sitt arbete vara verksam i skapelsen. ${ }^{147} \mathrm{M}$ änniskan har fått livet som en gåva av Gud och bör förvalta det väl. I Koranen står det att; "Helt visst ha Vi skapat människan för (ett liv av) slit, plågor och prövningar." "'48 Nyckelordet i grundtexten är kabad, som betyder plåga, prövning, bekymmer, vedermödor, slit. Uppfattningen är att det är mödosamt att leva, men vill man leva ett rättskaffens liv så verkar det ofrånkomligt att det innebär arbete. ${ }^{149}$

Islamologen Leif Stenberg säger; "En allmän teologisk bild av arbete kan sägas vara att mittfåran av sunnitisk islam anser att människan ska ha hög arbetsmoral och arbeta för sin, familjens och samhällets bästa." "'50 Det finns inom teologin och i religiösa berät-

147 Christer Hedin 1996: 114ff.

148 Koranens budskap 1998: Sura 90:4.

149 Koranens budskap 1998. Se Sura 90 not 3. 914.

150 Leif Stenberg 2005: 185. 
telser en idealbild av den fromme handelsmannen där det inte finns någon motsättning mellan tro och att tjäna pengar. Inkomsten ska dock användas på ett moraliskt sätt. ${ }^{151}$ Vanligtvis är plikten att arbeta och försörja en familj männens angelägenhet. Omständigheter när kvinnor tvingas bidra till familjens försörjning genom lönearbete kan ge upphov till familjekonflikter på grund av männens traditionella försörjningsplikt. ${ }^{152} \mathrm{En}$ uppfattning som inte är helt olik en tidigare mer spridd kristen attityd till förhållandet mellan kön och yrkesarbete.

\section{Utsagor om arbetet i ordspråk och talesätt}

Ordspråk är världen över en kollektiv och folklig källa till gängse attityder. Ordspråk är också en tidlös vishetslitteratur av rang. I traditionella samhällen var användandet av ordspråk ofta förbehållet de äldre. Detta motiveras med att det kräver en hel del erfarenhet för att veta vilket ordspråk som är lämpligt i en uppkommen situation. "De svenska ordspråken prisa arbetet som livets högsta goda och adelsmärke, men en och annan bitter ton blandar sig i hyllningskören." Så skriver Fredrik Ström i Svenska ordspråk. ${ }^{153}$

Den som arbetar sover gott för; "Arbetet gör sömnen söt" och den som arbetar kan förändra verkligheten; "Arbetet gör kullerstensgatan till ett salsgolv." Men det är inte alltid som det lönar sig att arbeta; "Arbete och möda, sill och bröd till föda." En kritisk bild av ett gammalt statarsverige? Lättjan hånas. "Lata armar och tomma tarmar höra ihop" och "Sömnigt tryna vinner blott snarksegrar."

Flera ordspråk pekar på ett samband mellan arbete, framgång och en mätt mage. "Människan är till arbete född". ${ }^{155}$ Att vara flitig är en folklig dygd och att vara lat är en dödssynd. Talesätt jag själv hört är 'Flit bygger berg' och 'För fliten är ingenting omöjligt'. "Arbete är det bästa tidsfördriv". ${ }^{156}$ I huvudsak finner vi i ordspråken en positiv syn på arbete. Ordspråk som "Arbetaren är sin lön värd" har en gammaltestamentlig dimension liksom förhållandet mellan att arbeta och ta igen sig; "Arbete utan hvila varar inte länge." ${ }^{157}$ Det finns i flera ordspråk en orsakskedja mellan lättja och fattigdom. Därtill föder ofta lathet fram laster av olika slag. ${ }^{158}$ Det gamla bondesamhällets strävsamhetsideal avlöses efter hand av andra attityder i mer moderna ordstäv. Bra betalt blir nu det primära. Arbete är ett nödvändigt ont, som i följande tvetydiga ordspråk; 'Det måste löna sig att tjäna pengar." ${ }_{159}$ I ordspråk från övriga Europa ser vi att det finns stora attitydlikheter. Människor ska arbeta och arbete är något gott i sig. Lathet ska undvikas och detta karaktärsdrag hånas ofta i ordspråk. ${ }^{160} \mathrm{I}$ exempel världen över finner vi liknande attityder. "Sysslolöshet alstrar oseder" menar ett kinesiskt talesätt. Gud/Himlen har en 151 Leif Stenberg 2005: 185.

152 Leif Stenberg 2005: 137, 186. Se även Naser Khader 1996: 10f, 92.

153 Fredrik Ström 1981: 44.

154 Fredrik Ström 1981: 44f.

155 Fredrik Ström 1981: 144.

156 Pelle Holm 1973: 26.

157 G.A Landgren 1889/1979: 7.

158 Pelle Holm 1973: 204, 225.

159 Ulf Palmenfelt 1991.

160 Jens A.A. Stabell Bilgrav 1985. 
mening med varje människa; "Om himlen skapar en människa har den en uppgift för henne." ${ }_{161}$

Det finns ett isländskt ordspråk som gisslar den overksamme - "lat man lämnar ogärna sovvarm säng." ${ }_{162}$ Ett arabiskt pekar på förhållandet att människan är bekväm av naturen och därför ska ha lön först efter utfört arbete; "Förskott på lön bromsar arbetet." 163 "Lättjan är en mäktig fiende" menar ett japanskt ordspråk. Ett ordspråk av persiskt ursprung pekar på förhållandet att arbetet ska vara njutningsfullt och frivilligt för att uppskattas eftersom "Förhatligt arbete gör dig till slav." ${ }_{164}$

Arbetsredskap ska hållas fria från rost och knivar ska vara vassa - å andra sidan; "En hantverkare med verktyg som alltid är blanka är en dålig arbetare." ${ }_{165}$ "Vingården kräver arbete, inte böner" är ett turkiskt ordspråk och "Utan svett ingen honung" menar ett slovenskt. ${ }^{166}$

Ett afrikanskt ordspråk säger att; "Arbete är bra så länge man inte glömmer bort att leva." ${ }^{167}$ Alltså balans mellan arbete och fritid är vad som eftersträvas. Det finns också afrikanska ordspråk som pekar på att den som slarvar med sådden får en dålig skörd. Noggrannhet är en dygd. Man finner även ordspråk från Afrika om behovet av att hjälpa varandra med större arbetsuppgifter. Gör du en helhjärtad arbetsinsats så gagnar det fler än dig själv. ${ }^{168}$ I Merutradition från Tanzania finns ordspråk om både lathet och företagsamhet. Det är bättre att någon tigger av dig än att du själv tigger från andra. Det finns ett värde i arbete och inställningen till personlig egendom i dessa Meruordspråk är positiv. Attityder indikerar - Ge inte upp för lätt därför att svårigheter är till för att övervinnas och uthållighet/tålamod är viktiga mänskliga egenskaper. ${ }^{169}$ Det finns också Yorubaordspråk från Nigeria som uttryckligen säger att när det gäller att förändra framtiden så måste du lita på dig själv. Det finns inga gudar som hjälper en oföretagsam eller lat person. Ditt viktigaste stöd är dina egna händer och armar. ${ }^{170}$ I första hand måste du tydligen lita till din egen förmåga.

Här slutar första delen av Roland Hallgrens essä om arbete. Den avslutande delen kommer i nästa nummer av HumaNetten och inkluderar en lista över referenser.

161 Herman Stolpe 1969a: 23, 39.

162 Herman Stolpe 1974: 24.

163 Herman Stolpe 1965: 47.

164 Ole Kragh 1981: 16, 183.

165 Herman Stolpe 1969b: 55.

166 Ivar Wallensteen/Gunnar Brusewitz 1991: 34f.

167 Ivar Wallensteen/Gunnar Brusewitz 1991: 38.

168 Herman Stolpe 1980: 29, 34, 72.

169 Raimo Harjula 1997: 61f, 65, 71.

170 Roland Hallgren 1988a: 139 och Roland Hallgren 1988b: 238:10.8. 